\title{
Comparison of Electrochemical Immunosensors and Aptasensors for Detection of Small Organic Molecules in Environment, Food Safety, Clinical and Public Security
}

\author{
Benoit Piro ${ }^{*}{ }^{\dagger}$, Shihui Shi ${ }^{\dagger}$, Steeve Reisberg ${ }^{\dagger}$, Vincent Noël ${ }^{\dagger}$ and Guillaume Anquetin ${ }^{\dagger}$ \\ University Paris Diderot, Sorbonne Paris Cité, ITODYS, UMR 7086 CNRS, 15 rue J-A de Baïf, Paris 75205, France; \\ shshh2008@hotmail.com (S.S.); steeve.reisberg@univ-paris-diderot.fr (S.R.); \\ vincent.noel@univ-paris-diderot.fr (V.N.); guillaume.anquetin@univ-paris-diderot.fr (G.A.) \\ * Correspondence: piro@univ-paris-diderot.fr; Tel.: +33-1-5727-7224 \\ + These authors contributed equally to this work. \\ Academic Editors: Nicole Jaffrezic-Renault and Carole Chaix \\ Received: 22 December 2015; Accepted: 19 February 2016; Published: 29 February 2016
}

\begin{abstract}
We review here the most frequently reported targets among the electrochemical immunosensors and aptasensors: antibiotics, bisphenol A, cocaine, ochratoxin A and estradiol. In each case, the immobilization procedures are described as well as the transduction schemes and the limits of detection. It is shown that limits of detections are generally two to three orders of magnitude lower for immunosensors than for aptasensors, due to the highest affinities of antibodies. No significant progresses have been made to improve these affinities, but transduction schemes were improved instead, which lead to a regular improvement of the limit of detections corresponding to $c a$. five orders of magnitude over these last 10 years. These progresses depend on the target, however.
\end{abstract}

Keywords: immunosensor; aptasensor; ciprofloxacin; enrofloxacin; ofloxacin; tetracyclines; neomycin; tobramycin; ampicillin; kanamycin; sulfonamides; bisphenol A; cocaine; ochratoxin A; estradiol

\section{Introduction}

There is a need to detect, for environment, security or medical purposes, various small organic molecules including antibiotics, drugs, toxins, pollutants, and so on. Although highly sensitive and selective, conventional chromatographic and spectroscopic analytical methods are time-consuming and laborious. Moreover, these techniques require expensive equipment, trained operators and tedious pretreatments. The need for disposable tools for monitoring these molecules encourages the development of simple, efficient, continuous, reliable, cost-effective and field-portable screening methods for analysis of environmental contaminants. Biosensors, and particularly electrochemical ones, appear to be an optimal technology. Since 1962 and the first enzyme-based glucose sensing device, there has been explosive development in biosensors in terms of scientific publications.

The figures of merit for biosensors first depend on the bioprobes which are chosen. Herein we reviewed, among the electrochemical biosensors, the most frequently reported bioprobes (antibodies, aptamers, and peptides, when applicable) for frequently reported targets: antibiotics, bisphenol A, cocaine, ochratoxin A and estradiol. In each case, the immobilization procedure was described, as well as the transduction scheme and the limit of detection. We will compare the results from one probe to another and discuss their efficiency for each target, respectively. 


\subsection{Immunosensors}

Immunosensors are probably the most reported biosensors; they are based on the binding properties of antibodies $(\mathrm{Ab})$ toward a specific target, called an antigen (Ag). The most frequent $\mathrm{Ab}$ reported in biosensors are immunoglobulins $\mathrm{G}(\mathrm{IgG})$, with a typical molecular weight of $150 \mathrm{kDa}$ and a mean size of $14 \times 9 \times 4 \mathrm{~nm}^{3}$. They are composed of two light and two heavy chains, linked by disulfide bonds to form a characteristic Y-shape [1,2] (Figure 1).

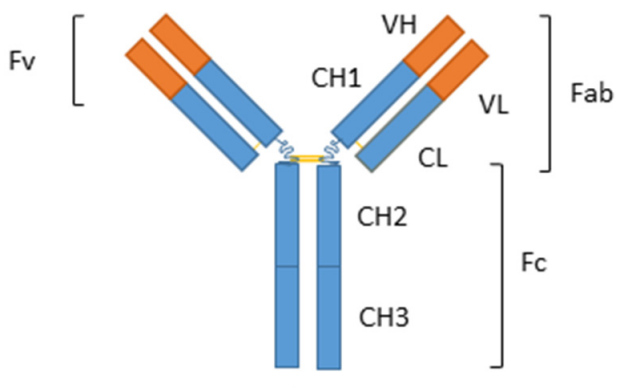

$\lg$

Figure 1. Immunoglobulin G (IgG) consists of two heavy chains (VH, CH1 and CH2) and two light chains (VL and CL). C are constant regions (which do not bring specificity to a given antigen) whereas $\mathrm{V}$ are variable regions, which bring specificity. As a consequence, antigens bind to the variable regions $\mathrm{VL}$ and $\mathrm{VH}$. In order to decrease the size of IgG, only the Fab (antigen binding fragment, composed of the $\mathrm{VH}, \mathrm{VL}, \mathrm{CH} 1$ and $\mathrm{CL}$ regions) can be employed. Reproduced from [3].

\subsection{Aptasensors}

Aptamers are short (15-100 bases) DNA or RNA strands that are able to bind to a specific target molecule. Aptamers are usually created by selecting them from a large random sequence pool (procedure called SELEX), but naturally occurring aptamers also exist. Aptamers can be used in sensors but were generally developed for clinical purposes, as drugs, for their interactions with expressed proteins. However, they can be selected for other targets than proteins, such as natural or synthetic small organic molecules. Aptamers are helpful in the detection of a wide range of compounds which are not (or too few) immunogenic to allow production of specific antibodies, so that immunosensors cannot be used [4].

\subsection{Peptide Sensors}

The interest in replacing antibodies with peptides is the same as for aptamers [4]. In recent years, the use of peptides as sensing probes for constructing electrochemical biosensors has received great attention because, compared to antibodies or aptamers, peptides are smaller and rarely denaturized when immobilized on the sensing surface. However, even if various peptide sequences exhibiting affinity to particular substrates have been found, peptides capable of recognizing low molecular weight organic compounds with sufficient affinity have rarely been reported as of yet.

\section{Substances and Receptors}

The most frequently reported electrochemical biosensing approaches are comprehensively reviewed for each molecule of interest that we selected.

\subsection{Antibiotics}

Immunosensors for drugs detection and quantification have been described for over 30 years. The most reported drugs are antibiotics and, more particularly, ciprofloxacin, enrofloxacin, ofloxacin, tetracycline, neomycin, tobramycin, ampicillin, kanamycin and sulfonamides (Figure 2). Both antibodies and aptamers were used as probes for these molecules. 
<smiles>O=C(O)c1cn(C2CC2)c2cc(N3CCNCC3)c(F)cc2c1=O</smiles>

(a)<smiles>CN(C)C1C(O)=C(C(N)=O)C(=O)[C@]2(O)C(O)=C3C(=O)c4c(O)cccc4[C@@](C)(O)[C@H]3C[C@H]12</smiles>

(d)<smiles>CC1(C)S[C@H]2C(NC(=O)C(N)c3ccccc3)C(=O)N2[C@H]1C(=O)O</smiles>

(g)<smiles>CCN1CCN(c2cc3c(cc2F)c(=O)c(C(=O)O)cn3C2CC2)CC1</smiles>

(b)

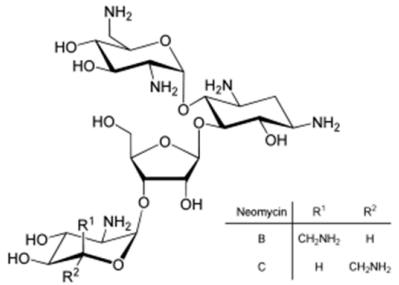

(e)

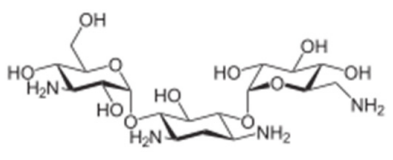

(h)<smiles>C[C@@H]1COc2c(N3CCN(C)CC3)c(F)cc3c(=O)c(C(=O)O)cn1c23</smiles>

(c)

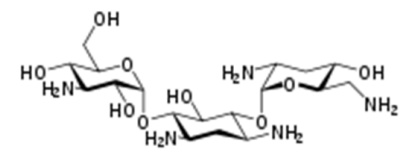

(f)<smiles>NS(=O)(=O)c1cc2c(cc1Cl)NCNS2(=O)=O</smiles>

(i)

Figure 2. Chemical structures of (a) ciprofloxacin; (b) enrofloxacin; (c) ofloxacin; (d) tetracycline; (e) neomycin; (f) tobramycin; (g) ampicillin; (h) kanamycin and (i) hydrochlorothiazide (a sulfonamide).

\subsubsection{Antibodies}

In 2007, Garifallou et al. [5] described a label-free immunosensor for ciprofloxacin based on antibody-modified screen-printed carbon electrodes (SPEs), using electrochemical impedance spectroscopy (EIS) for detection. The antibody (Ab) was immobilized through biotin-avidin interactions. The impedance was reported to increase with ciprofloxacin concentration, with a linearity domain between 1 and $100 \mathrm{ng} \cdot \mathrm{mL}^{-1}(3 \mathrm{nM}-0.3 \mathrm{nM})$. The same year, another group proposed a similar approach, but the $\mathrm{Ab}$ was immobilized by peptide coupling, presenting must less steric hindrance than the biotin-avidin coupling, which allowed to decrease the LoD down to $10 \mathrm{pg} \cdot \mathrm{mL}^{-1}$ (30 pM) [6]. In 2009, the same group published an innovative immunosensor where ciprofloxacin was first grafted on the electrode, onto which the anti-ciprofloxacin $\mathrm{Ab}$ was complexed (Figure 3). In the presence of ciprofloxacin, the antibody was displaced in solution inducing strong changes in the impedance of the electrode; the LoD was of $c a .1 \mathrm{pg} \cdot \mathrm{mL}^{-1}$ (3 pM) [7].

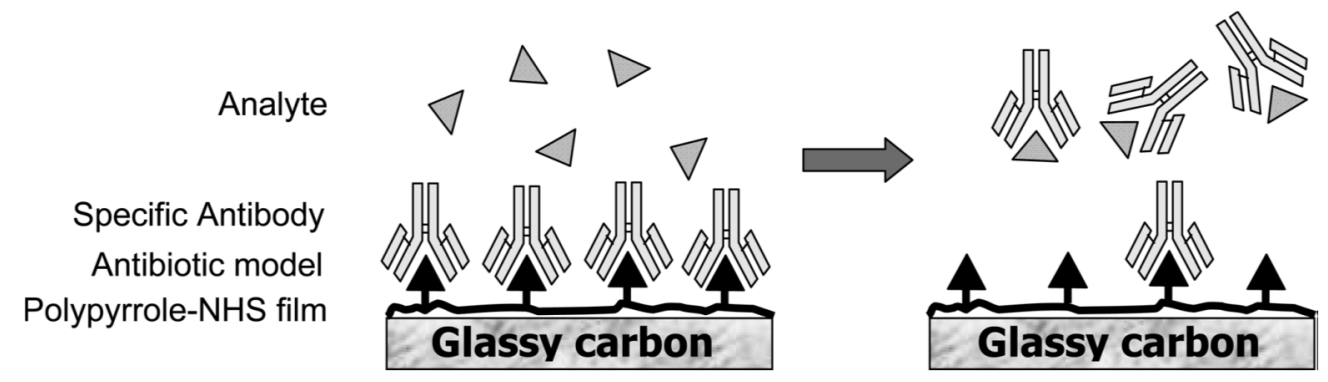

Figure 3. Functioning principle of the immunosensor for ciprofloxacin based on anti-ciprofloxacin antibody displacement. Reprinted with permission from [7]. Copyright 2009 American Chemical Society.

Detection of enrofloxacin on SAM-modified electrodes gave similar results. For example, Wu et al., (2009) reported EIS characterization of interactions between enrofloxacin and its $\mathrm{Ab}$ 
immobilized on a SAM-modified Au electrode; this interaction caused an increase of electron transfer resistance (Rct) with a LoD of $1 \mathrm{ng} \cdot \mathrm{mL}^{-1}(3 \mathrm{nM})$. [8] Zhang et al., (2013) described a competitive enzyme-amplified immunosensor (using the horseradish peroxidase enzyme, HRP) based on gold nanoclusters/polypyrrole (PPy)-functionalized electrodes, for sensitive detection of ofloxacin [9], which exhibited a response in the range $0.08-410 \mathrm{ng} \cdot \mathrm{mL}^{-1}$, with a LoD of $30 \mathrm{pg} \cdot \mathrm{mL}^{-1}(0.1 \mathrm{nM})$.

The use of magnetic beads (MBs) can improve sensitivity. For example, Zacco et al. [10] described an electrochemical immunosensor for the detection of sulfonamide antibiotics based on magnetic beads, amplified with the use of HRP as label. The LoD was $c a .1 \mu \mathrm{g} \cdot \mathrm{L}^{-1}(6 \mathrm{nM})$. Centi et al. described a more complicated transduction architecture [11], using protein A immobilized on magnetic microbeads (MBs) to bind the specific Ab. A competition assay between the target analyte and the HRP-labeled sulfonamide target was carried out. The LoD was ca. $1 \mathrm{ng} \cdot \mathrm{mL}^{-1}$ (4 nM). Conzuelo et al. (2012) [12] used a selective capture $\mathrm{Ab}$ immobilized on the surface of MBs for tetracycline detection. A direct competitive immunoassay using HRP for the enzymatic labeling was performed, with hydroquinone (HQ) as redox mediator. They obtained low LoD (in the $\mathrm{ng} \cdot \mathrm{mL}^{-1}$ range, i.e., the $\mathrm{nM}$ range) for 4 tetracycline antibiotics. The same group described more recently a similar procedure where Abs were immobilized by the diazonium route [13]. Que et al. [14] nanostructured their electrodes for tetracycline detection using platinum NPs deposited on graphene nanosheets (GN). This way, retaining a competitive immunoassay format, they significantly lowered the LoD down to $6 \mathrm{pg} \cdot \mathrm{mL}^{-1}(13 \mathrm{pM})$.

Even if, as it is generally the case for immunosensors, enzyme-labeling is the dominant strategy for improving sensitivity, it appears that non-enzymatic amplification (through increase of the active surface area or use of catalytic reactions) are often more efficient than classical (HRP) enzymatic amplification.

\subsubsection{Aptamers}

Aptamers have been used for tetracycline detection as well, by Kim et al., in 2009. They used interdigitated gold electrodes modified with a 76-mer thiol-ssDNA aptamer. The dissociation constant (KD) of this aptamer for oxytetracycline was $11 \mathrm{nM}$. Transduction was explained by the fact that the redox probe diffusing in solution $\left(\mathrm{Fe}(\mathrm{CN})_{6}{ }^{3-/ 4-}\right.$ ) was influenced by interactions between the aptamers and the target molecules. The dynamic range was 1-100 $\mathrm{nM}$ (LoD of $1 \mathrm{nM}$, i.e., $0.3 \mathrm{ng} \cdot \mathrm{mL}^{-1}$ ) [15].

In 2010, the same group [16] described similar results but using a streptavidin-modified screen-printed gold electrode onto which biotinylated ssDNA aptamers were immobilized. Still using $\mathrm{CV}$ and SWV with $\mathrm{Fe}(\mathrm{CN})_{6}{ }^{3-/ 4-}$ as diffusing probe, they found a LoD for tetracycline of $10 \mathrm{nM}$ (i.e., $\left.3 \mathrm{ng} \cdot \mathrm{mL}^{-1}\right)$. In another similar example, Zhou et al. [17], still using diffusing $\mathrm{Fe}(\mathrm{CN})_{6}{ }^{3-/ 4-}$ as redox probe, described an electrochemical tetracycline aptasensor involving multiwalled carbon nanotubes (MWCNTs), the electroactivity of which being decreased due to the formation of aptamer-tetracycline complexes. The peak current changes obtained by differential pulse voltammetry (DPV) increased linearly with tetracycline concentrations from $5 \mathrm{pM}\left(1.5 \mathrm{ng} \cdot \mathrm{mL}^{-1}\right)$ to $50 \mu \mathrm{M}$. Chen et al., in 2014 [18], used EIS with a 13 bases-long aptamer; a linear relationship between the log concentration of tetracycline and the charge transfer resistance was found from $5 \mathrm{ng} \cdot \mathrm{mL}^{-1}$ to $5 \mu \mathrm{g} \cdot \mathrm{mL}^{-1}$; the LoD was $1 \mathrm{ng} \cdot \mathrm{mL}^{-1}$ (ca. $2 \mathrm{nM}$ ). This LoD was significantly lower than the $\mathrm{K}_{\mathrm{D}}$ determined by the authors using calorimetry $\left(K_{D}\right.$ of $\left.50 \mu \mathrm{M}\right)$. Shen et al. [19] used differential pulse voltammetry (DPV) with Prussian blue immobilized onto AuNPs modified with a 79 bases long aptamer having a KD of $63 \mathrm{nM}$ for tetracycline. The detection range was linear from $10^{-9}$ to $10^{-5} \mathrm{M}$, with a LoD of $0.3 \mathrm{nM}$ (i.e., $0.1 \mathrm{ng} \cdot \mathrm{mL}^{-1}$ ).

The first label-free electrochemical RNA-based aptasensor for detection of an antibiotic was described in 2007 for neomycin (Figure 4) [20]. The authors described a competitive displacement assay and used EIS. The selectivity of the RNA aptamer allowed determination of neomycin even in biological samples of high protein content. The sensitivity was not excellent, around $1 \mu \mathrm{M}$, close to the $\mathrm{K}_{\mathrm{D}}$ of the aptamers-neomycin complex. 


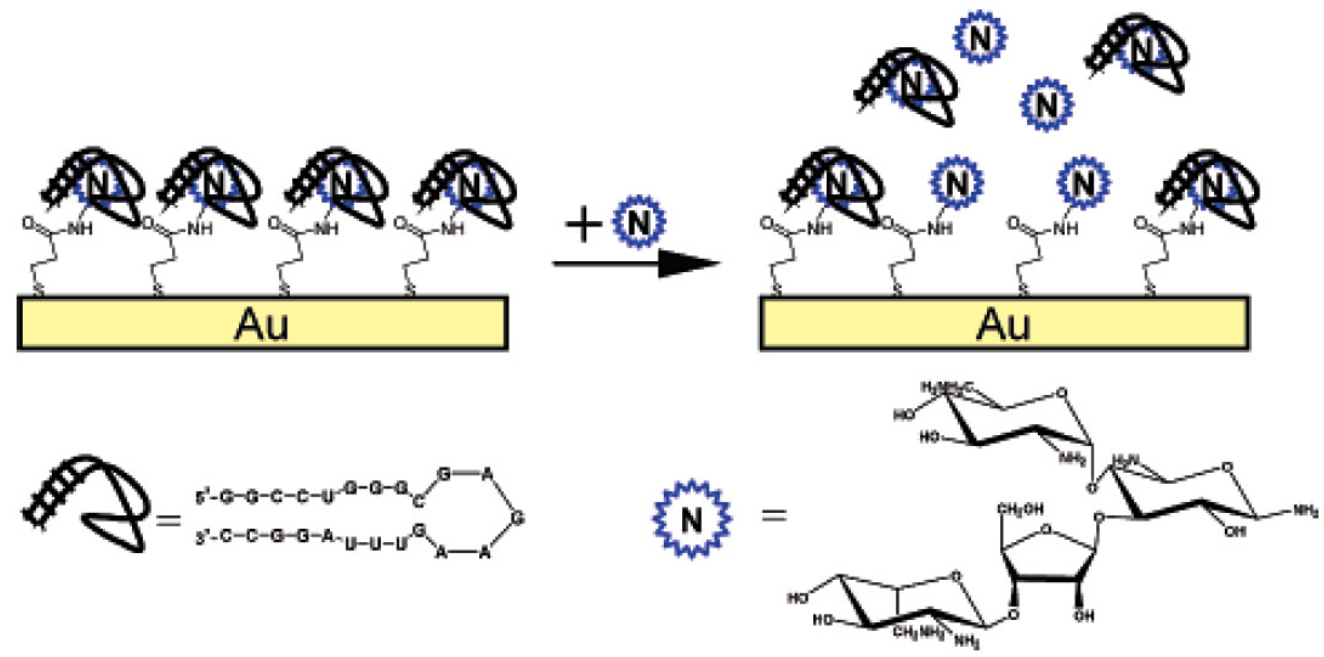

Figure 4. Schematic illustration of the modified electrode and the competitive assay between complexed neomycin on the electrode surface and freely diffusion neomycin. Reprinted with permission from [20]. Copyright 2007 American Chemical Society.

The previous examples are mostly based on the use of a redox probe diffusing in solution, which brings sensitivity but is obviously difficult to integrate when a system is really applied. In 2010, the group of Plaxco showed that classical RNA aptamers, even if sensitive to nuclease, can be used in biological samples providing that these samples were previously ultra-filtrated. They demonstrated the detection of tobramycin in the range 2-6 $\mu \mathrm{M}\left(4-10 \mu \mathrm{g} \cdot \mathrm{mL}^{-1}\right)$ in blood using a methylene blue (MB)-modified RNA aptamer sequence 5'-HS-GGG ACU UGG UUU AGG UAA UGA GUC CC-NH-MB-3', having a dissociation constant of $13.2 \mu \mathrm{M}$ for tobramycin (measured in homogenous conditions) [21]. They have shown that the $\mathrm{K}_{\mathrm{D}}$ increased at least by one order of magnitude in heterogeneous conditions. A similar approach has been reported in several following papers, with variable results. For example, Liu et al., in 2014 [22], reported an electrochemical DNA aptamer-based tobramycin sensor (5'-HS-C6-GGG ACT TGG TTT AGG TAA TGA GTC CC-MB-3' sequence, immobilized on gold microelectrodes). Despite the electrochemical deposition of dendritic gold nanostructures, they reported a high LoD of $c a .1 \mathrm{mM}\left(\mathrm{K}_{\mathrm{D}}\right.$ in the $\mathrm{mM}$ range as well).

The reagentless detection of small molecules using aptamers is not straightforward because the spatial reorganization triggered by the analyte is often small. To address this issue, Gonzales-Fernandes et al. described a strategy based on competition between tobramycin immobilized on magnetic microbeads (MBs) and free tobramycin diffusing in solution. Detection was made by post-labeling aptamers with an enzyme (alkaline phosphatase, AlkP) through the biotin-avidin conjugate. Using a 27-mer anti-tobramycin RNA aptamer (5'-GGC ACG AGG UUU AGC UAC ACU CGU GCC- $3^{\prime}$ ), they found a linear response in the range 5-500 $\mu \mathrm{M}$ [23]. The same authors described later a slightly modified architecture for tobramycin detection using an antibody-antigen association for introducing the enzyme conjugate on the aptamers [24]. Compared with the biotin-avidin approach, the limit of detection was lowered down to $0.1 \mu \mathrm{M}$. The authors explained this behavior by the steric hindrance of avidin, which impeded detection.

As shown, reported LoD stay too high for practical applications when aptamers are labeled with redox probes. Another way to detect a molecule through the use of aptamers is to us them as pre-concentrators immobilized on the electrode surface, followed by electro-oxidation or electroreduction of the target molecule directly on the electrode, without any other intermediate. Zhu et al. [25] proposed such an approach applied to kanamycin and involving AuNPs. The authors used a 22-bases DNA aptamer (5'-TGG GGG TTG AGG CTA AGC CGA C-3') showing a high binding affinity to kanamycin $\left(K_{\mathrm{D}}=79 \mathrm{nM}\right)$, immobilized onto AuNPs modified with 
poly-[2,5-di-(2-thienyl)-1H-pyrrole-1-(p-benzoic acid)]. Kanamycin detection was achieved by CV and linear sweep voltammetry (LSV). The calibration plot showed a linear range from $0.05 \mu \mathrm{M}$ to $9.0 \mu \mathrm{M}$ with a LoD significantly lowered $\left(10 \mathrm{nM}\right.$, i.e., $\left.5 \mathrm{ng} \cdot \mathrm{mL}^{-1}\right)$ compared to the previously reported architectures. Compared to the other amplification strategies used with aptamers, this approach of preconcentration followed by stripping (adsorptive stripping voltammetry-ASV) is certainly the one which leads to the highest sensitivities after EIS.

Lastly, it should also be stressed that attempts to make all-polymer, all-printed, electrochemical sensors were reported. For example, Dapra et al. [26] presented an all-polymer electrochemical biosensor based on conductive bilayer consisting of tosylate-doped poly(3,4-ethylenedioxythiophene) (PEDOT-TsO) and its hydroxymethyl derivative which was covalently functionalized with two short aptamer probes with affinity to ampicillin or kanamycin A, respectively. The ampicillin DNA aptamer sequence was 5'-GCG GGC GGT TGT ATA GCG G-3' $\left(\mathrm{K}_{\mathrm{D}}=13 \mathrm{nM}\right)$ and the kanamycin one was $5^{\prime}$-TGG GGG TTG AGG CTA AGC CGA-3' $\left(\mathrm{K}_{\mathrm{D}}=79 \mathrm{nM}\right)$. Using EIS, they were able to detect ampicillin in a concentration range from $100 \mathrm{pM}$ to $1 \mu \mathrm{M}$ and kanamycin A from $10 \mathrm{nM}$ to $1 \mathrm{mM}$. As discussed by the authors, the low LoD and wide dynamic range of their biosensor could be attributed not only to the high affinity of the DNA probes but also to their device properties. Indeed, for a similar probe applied in different techniques, LoDs can change over three orders of magnitude.

All these results are summarized in Table 1. As shown, tetracycline is a common target for Abs and aptamers. LoDs in the nM range were obtained for both capture probes, without significant differences. For a same probe, it appears that electrode nanostructuration leads to an improvement of the detection limit of at least one order of magnitude. It is also interesting to note that methods involving enzyme amplifications applied with aptamer probes do not appear to be more sensitive than non-amplified methods.

Table 1. Figures of merit of selected immunosensors and aptasensors for detection of some antibiotics: ciprofloxacin (CF), ofloxacin (OFL), sulfonamides (SA), tetracyclines (TC), neomycin (NEO), tobramycin (TOB), kanamycin (KAN), ampicillin (AMP).

\begin{tabular}{|c|c|c|c|c|}
\hline Targets & Bioreceptors & LoD & Transduction \& Analytical Methods & Ref. \\
\hline $\mathrm{CF}$ & $\mathrm{Ab}$ & $3 \mathrm{nM}$ & EIS & [5] \\
\hline $\mathrm{CF}$ & $\mathrm{Ab}$ & $30 \mathrm{pM}$ & EIS & [6] \\
\hline $\mathrm{CF}$ & $\mathrm{Ab}$ & $3 \mathrm{nM}$ & EIS & [7] \\
\hline $\mathrm{CF}$ & $\mathrm{Ab}$ & $3 \mathrm{nM}$ & SAM/EIS & [8] \\
\hline OFL & $\mathrm{Ab}$ & $0.1 \mathrm{nM}$ & $\mathrm{HRP} / \mathrm{AuNPs} / \mathrm{PPy} / \mathrm{CV}$ & [9] \\
\hline SA & $\mathrm{Ab}$ & $6 \mathrm{nM}$ & MBs/HRP/CV & [10] \\
\hline $\mathrm{TC}$ & $\mathrm{Ab}$ & $4 \mathrm{nM}$ & $\mathrm{MBs} / \mathrm{HRP} / \mathrm{CV}$ & [11] \\
\hline $\mathrm{TC}$ & $\mathrm{Ab}$ & $1 \mathrm{nM}$ & $\mathrm{HRP} / \mathrm{HQ} / \mathrm{CV}$ & [12] \\
\hline $\mathrm{TC}$ & $\mathrm{Ab}$ & $13 \mathrm{pM}$ & Platinum-catalyzed HER/CV & [14] \\
\hline $\mathrm{TC}$ & Aptamer & $1 \mathrm{nM}$ & $\mathrm{Fe}(\mathrm{CN})_{6}^{3-/ 4-} / \mathrm{CV}$ & [15] \\
\hline $\mathrm{TC}$ & Aptamer & $10 \mathrm{nM}$ & $\mathrm{Fe}(\mathrm{CN})_{6}^{3-/ 4-} / \mathrm{CV} / \mathrm{SWV}$ & [16] \\
\hline $\mathrm{TC}$ & Aptamer & $5 \mathrm{pM}$ & $\mathrm{CNTs} / \mathrm{Fe}(\mathrm{CN})_{6}^{3-/ 4-} / \mathrm{DPV}$ & [17] \\
\hline $\mathrm{TC}$ & Aptamer & $2 \mathrm{nM}$ & EIS & [18] \\
\hline $\mathrm{TC}$ & Aptamer & $0.3 \mathrm{nM}$ & $\mathrm{PB} / \mathrm{DPV}$ & [19] \\
\hline $\mathrm{NEO}$ & Aptamer & $1 \mu \mathrm{M}$ & EIS & [20] \\
\hline TOB & Aptamer & $2 \mu \mathrm{M}$ & MB label/CV & [21] \\
\hline TOB & Aptamer & $1 \mathrm{mM}$ & AuNPs/MB label/CV & [22] \\
\hline TOB & Aptamer & $5 \mu \mathrm{M}$ & $\mathrm{MBs} / \mathrm{AlkP} / \mathrm{CV}$ & [23] \\
\hline TOB & Aptamer & $0.1 \mu \mathrm{M}$ & $\mathrm{MBs} / \mathrm{AlkP} / \mathrm{CV}$ & [24] \\
\hline KAN & Aptamer & $10 \mathrm{nM}$ & AuNPs/CV & [25] \\
\hline KAN & Aptamer & $10 \mathrm{nM}$ & PEDOT/EIS & [26] \\
\hline AMP & Aptamer & $100 \mathrm{pM}$ & PEDOT/EIS & [26] \\
\hline
\end{tabular}

Note: LoD (limit of detection); HRP (horseradish peroxidase); PPy (polypyrrole); HER (hydrogen evolution reaction), CV (cyclic voltammetry); SWV (square wave voltammetry); MBs (magnetic beads); CNTs (carbon nanotubes); PB (prussian blue); MB (methylene blue); AuNPs (gold nanoparticles). 


\subsection{Bisphenol A}

Bisphenol-A (BPA) (Figure 5) is a well-known and much studied contaminant causing a wide range of health problems to living beings, especially the young. In 2013, Ragavan et al. reviewed the various principles, mechanisms and performances of BPA biosensors available in the literature [27], among which are found electrochemical immuno- and apta-sensors.

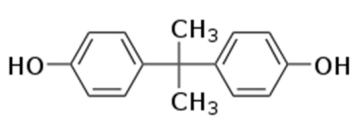

(a)

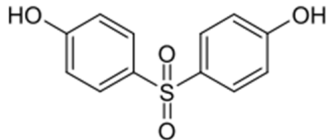

(b)

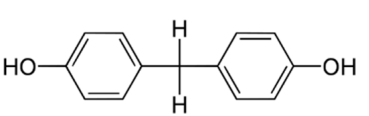

(c)

Figure 5. Chemical structure of (a) bisphenol A; (b) bisphenol S and (c) bisphenol F.

\subsubsection{Antibodies}

The first electrochemical immunosensor for BPA detection was described very recently, in 2007, by Rahman et al. and Piao et al. (from the same research group) [28,29]. The immunosensor was fabricated by covalent binding of the $\mathrm{Ab}$ onto $\mathrm{COOH}$-functionalized polythiophene. It showed specific recognition of BPA on a linear dynamic range between 1 and $100 \mathrm{ng} \cdot \mathrm{mL}^{-1}$. The LoD was $0.3 \mathrm{ng} \cdot \mathrm{mL}^{-1}$ $(1.3 \mathrm{nM})$. Wang et al. published recently a label-free electrochemical competitive immunosensor able to detect BPA directly with a limit of detection of $2 \mathrm{pg} \cdot \mathrm{mL}^{-1}(9 \mathrm{pM})$. Characterizations made by SWV showed that the polymer film presented a current decrease upon anti-BPA binding and an opposite current increase upon BPA addition in solution [30]. The difference in sensitivity between the results of Rahman et al., Piao et al. and Wang et al. could be explained by the nature of transduction scheme. Indeed, the latter reported the use of a competitive immunodisplacement approach whereas the two first articles reported a classical $\mathrm{Ab}-\mathrm{Ag}$ interaction where the $\mathrm{Ab}$ was covalently immobilized on the electrode.

\subsubsection{Aptamers}

Even if strategies to develop antibodies towards bisphenol A, including antibodies with good affinities, have been reported (see above), DNA aptamers specific to BPA were reported to be of higher affinity than antibodies (in the $\mathrm{nM}$ range). For this reason, lower LoDs have been reached. Electrochemical transduction was investigated by Xue et al. [31]. They used a specific DNA aptamer against BPA (5'-CCG GTG GGT GGT CAG GTG GGA TAG CGT TCC GCG TAT GGC CCA GCG CAT CAC GGG TTC GCA CCA-3'), immobilized on the surface of a gold electrode via self-assembly and hybridized with its complementary strand. A redox intercalator was added. The detection of BPA was based on the competitive recognition of BPA by the immobilized aptamer on the surface of the electrode, which dehybridized the complementary strand and therefore freed the redox intercalator into solution. The redox signal was recorded by CV. The LoD was $0.3 \mathrm{pg} \cdot \mathrm{mL}^{-1}(1 \mathrm{pM})$.

Graphene-modified glassy carbon (GC) electrodes were also investigated, which confers higher specific active areas. Zhou et al. [32] immobilized AuNPs on GR-modified electrodes and used freely diffusing $\mathrm{Fe}(\mathrm{CN})_{6}{ }^{3-/ 4-}$ as electrochemical probe. The DPV peak current of $\mathrm{Fe}(\mathrm{CN})_{6}{ }^{3-/ 4-}$ changed linearly with the concentration of BPA in the range from $10 \mathrm{nM}$ to $10 \mu \mathrm{M}$, with a LoD of $5 \mathrm{nM}$ ( $c a$. $\left.1 \mathrm{ng} \cdot \mathrm{mL}^{-1}\right)$. They used the same aptamer sequence as the previous reference.

\subsubsection{Peptides}

Specific peptides were also reported for BPA. Yang et al. [33] described an electrochemical sensor using the peptide sequence Cys-Lys-Ser-Leu-Glu-Asn-Ser-Tyr-Cys (CKSLENSYC) capable of recognizing BPA with high specificity (isolated using a phage display technique). Peptides were immobilized by thiol adsorption on Au electrodes and BPA was sensed using DPV with 
$\mathrm{Fe}(\mathrm{CN})_{6}{ }^{3-/ 4-}$ as redox probe, with a broad detection range between $1 \mathrm{nM}$ and $5 \mu \mathrm{M}$ (LoD of $1 \mathrm{nM}$, i.e., $\left.0.2 \mathrm{ng} \cdot \mathrm{mL}^{-1}\right)$. Kim et al. also reported very recently the electrochemical detection of BPA with a protein immobilized on RGO electrodes [34]. The protein was a recombinant one obtained by fusing the disulfide-constrained high affinity BPA binding peptide (CKSLENSYC, as reported by Yang et al.) to the C-terminus of the Lac repressor (Lad), which is a large protein $(140 \AA \times 60 \AA \times 45 \AA)$. This modified protein was immobilized on RGO by heat-denaturation, so that it can adsorb by $\pi$-stacking interactions. EIS was used (the redox reaction is not given in their manuscript) to probe the presence

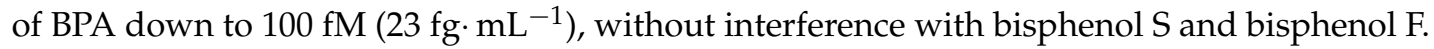

All these results are summarized in Table 2. Considering that BPA, Abs, aptamers and peptides have yet been poorly reported in the literature, an unbiased comparison is not possible.

Table 2. Figures of merit of selected immunosensors, aptasensors and peptide sensors for detection of bisphenol A.

\begin{tabular}{cccc}
\hline Bioreceptors & LoD & Transduction and Analytical Methods & Ref. \\
\hline $\mathrm{Ab}$ & $1.3 \mathrm{nM}$ & Conducting polymer \& EIS & {$[28,29]$} \\
$\mathrm{Ab}$ & $9 \mathrm{pM}$ & Conducting polymer \& SWV & {$[30]$} \\
Aptamer & $1 \mathrm{pM}$ & $\mathrm{Fe}(\mathrm{CN})_{6}{ }^{3-/ 4} / \mathrm{EIS}$ & {$[31]$} \\
Aptamer & $5 \mathrm{nM}$ & Graphene $/ \mathrm{Fe}(\mathrm{CN})_{6}{ }^{3-/ 4} / \mathrm{DPV}$ & {$[32]$} \\
Peptide & $1 \mathrm{nM}$ & $\mathrm{SAM} / \mathrm{Fe}(\mathrm{CN})_{6}{ }^{3-} / 4 / \mathrm{DPV}$ & {$[33]$} \\
Peptide & $100 \mathrm{fM}$ & Graphene oxide/EIS & {$[34]$} \\
\hline
\end{tabular}

\subsection{Cocaine}

Cocaine (Figure 6) is the most frequently used illegal drug after cannabis (ca. 15 million users around the world) and directly provokes several thousands of deaths each year. Its detection, e.g., in airports, is routinely made with trained dogs, but more automatic systems would be extremely useful.

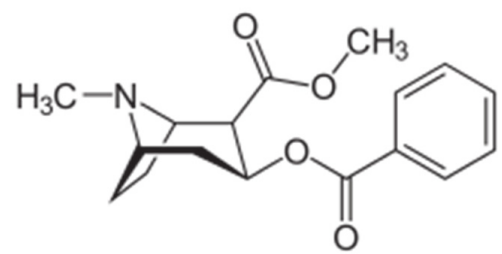

Figure 6. Chemical structure of cocaine, methyl(1R,2R,3S,5S)-3-(benzoyloxy)-8-methyl-8-azabicyclo[3.2.1] octane-2-carboxylate.

\subsubsection{Antibodies}

There are very few examples of immunosensors dedicated to narcotics. The two very first articles were published in 1998 and dealt with cocaine detection. In 1998, Bauer et al. [35] proposed an automated amplified flow immunoassay for cocaine using the alkaline phosphatase (AlkP) enzyme label for amplification and transduction. The LoD was $380 \mathrm{pM}$. The same year, Suleiman et al. [36] described an amperometric immunosensor for cocaine using HRP and, as in the case of Bauer et al., an oxygen electrode. Cocaine was quantified in the range $10^{-7}-10^{-5} \mathrm{M}$, i.e., at too high concentrations for being of practical use.

More than 15 years passed before another example of immunosensor for cocaine or morphine was published. It is only recently that, considering the good results obtained by aptamer-based cocaine sensors, researchers began again to study cocaine-specific antibodies. The literature remains very limited, however. Yang et al. [37] described an immunosensor based on a SAM-modified Au electrode for detection of morphine and methamphetamine (MA), using EIS, with a low LoD of $10 \mathrm{pg} \cdot \mathrm{L}^{-1}$ (33 fM). For more information, a very recent (2015) book chapter published by Ozkan et al., is available, dealing with electrochemical biosensors for drug analysis [38]. 


\subsubsection{Aptamers}

By contrast, aptamer-based sensors for cocaine were more frequently reported. The first significant work on this topic was published in 2006 by Baker et al. [39]. They demonstrated a rapid, label-free, electrochemical method for the detection of small molecules in general, based on a target-induced conformational change, unaffected by non-specific contaminants, and illustrated by the detection of cocaine in blood serum, saliva, and other complex samples. Two DNA aptamers were investigated (GAC AAG GAA AAT CCT TCA ATG AAG TGG GTC and AGA CAA GGA AAA TCC TTC AAT GAA GTG GGT CG) with $\mathrm{K}_{\mathrm{D}}$ of approximately $90 \mu \mathrm{M}$ each, which allowed a LoD below $10 \mu \mathrm{M}$ (Figure 7); however, these were too high to allow for practical applications.

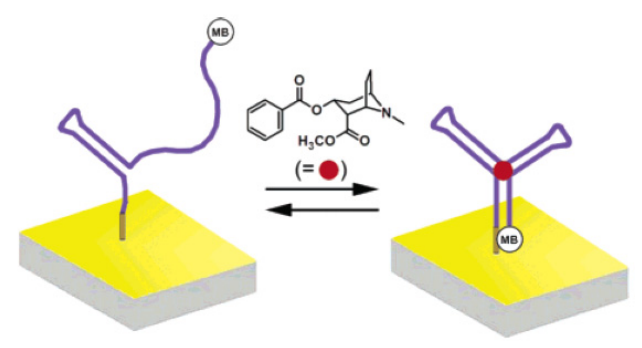

(A)

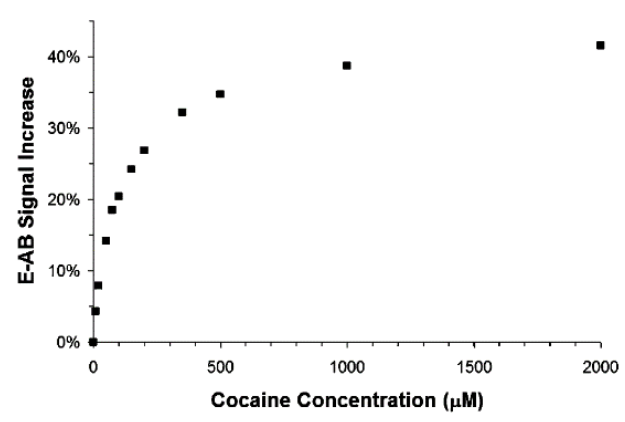

(B)

Figure 7. (A) Working principle of the aptamer-based cocaine biosensor of Baker et al. MB (methylene blue) was used as redox label (B) Corresponding calibration curve. Reprinted with permission from [39]. Copyright 2006 American Chemical Society.

The same group reported later [40] a sandwich assay based on single aptamer sequences labeled with MB and able to detect cocaine. The principle relied on the formation of a complex made of two-strand aptamers which was stabilized together by the presence of the target (Figure 8). Even though the $K_{D}$ was estimated at around $1 \mathrm{mM}$, the authors reported a significantly lower LoD of $c a$. $1 \mu \mathrm{M}$. The limit of quantification (LoQ), however, should be between 0.1 and $1 \mathrm{mM}$.
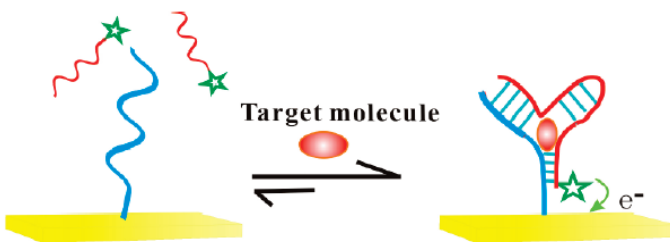

(A)

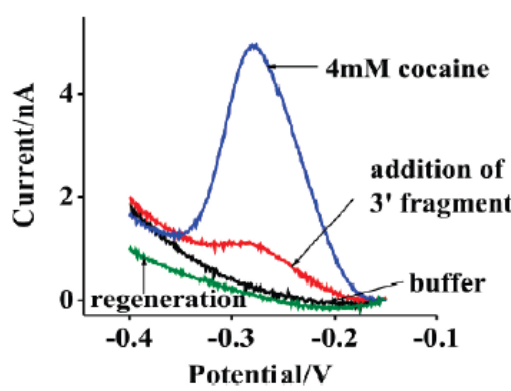

(B)

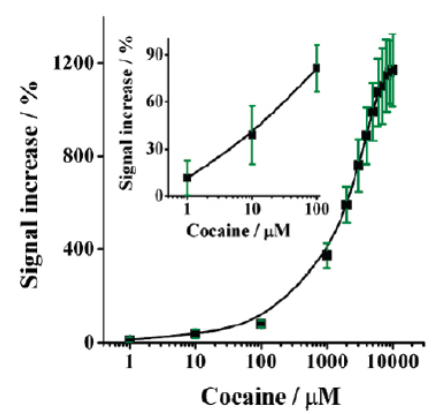

(C)

Figure 8. (A) Target binding stabilizes the association of the two aptamer strands, leading to a large increase in faradaic current; (B) when the target is present; (C) Calibration curve. Reprinted with permission from [40]. Copyright 2009 American Chemical Society. 
On the same principle, Golub et al. [41] described two anti-cocaine aptamer subunits, where one subunit was assembled on an Au electrode, and the second aptamer subunit was labeled with Pt-NPs. The supramolecular Pt-NPs-aptamer subunits-cocaine complex allowed the detection of cocaine by the electrocatalyzed reduction of $\mathrm{H}_{2} \mathrm{O}_{2}$ on the Pt-NPs. The detection limit was in the range of $10^{-6}-10^{-5} \mathrm{M}$ (Figure 9).

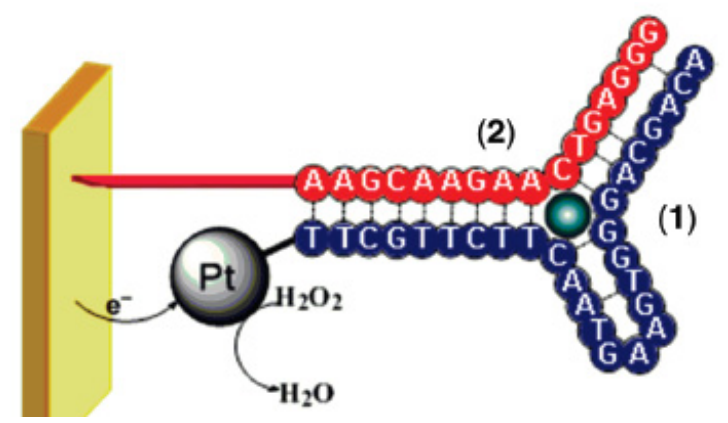

Figure 9. Supramolecular complex of Pt-NPs-aptamer subunit (1) and second aptamer subunit immobilized on the gold surface (2). Adapted with permission from [41]. Copyright 2009 American Chemical Society.

Again regarding the use of a two-strand aptamers, Du et al. [42] constructed a label-free electrochemical aptasensor using layer-by-layer self-assembly of Fc-modified poly(ethyleneimine), with a LoD of $0.1 \mu \mathrm{M}$. A similar approach was described by Zhang et al. [43] using a primary immobilized aptamer and a secondary aptamer labeled with various quantum dots used in the same way than in bar-code assays, i.e., different QDs yield distinct electrochemical signatures. A LoD of $50 \mathrm{nM}$ was obtained. Another approach using multiple stems was described by Hua et al. [44] (with the cocaine DNA aptamer 5'-GGG AGA CAA GGA TAA ATC CTT CAA TGA AGT GGG TCT CCC $\left.-3^{\prime}\right)$, where the transduction step was also based on a hairpin structure. The linear range was from $10^{-9} \mathrm{M}$ to $10^{-6} \mathrm{M}$. Again using the multiple stem approach, Zhang et al. [45] investigated the formation of the corresponding supramolecular aptamer fragments/cocaine complex by EIS in the presence of $\mathrm{Fe}(\mathrm{CN})_{6}{ }^{3-/ 4-}$. Cocaine concentrations as low as $100 \mathrm{nM}$ were detected. Very recently, Roushani and Shahdost-Fard [46] described a sensor based on the same principle with aptamer-functionalized AuNPs. The interaction of cocaine with the aptamer caused the AuNPs to come close to the electrode surface and impede diffusion of the redox probe $\mathrm{Fe}(\mathrm{CN})_{6}{ }^{3-} / 4-$. Monitored with DPV, the detection limit was 100 pM. The same authors described a similar approach using AgNPs [47] and riboflavin as the redox probe; the LoD was equivalent, i.e., $150 \mathrm{pM}$.

Jiang et al. [48] used the same supramolecular aptamer sequences for detection of cocaine using an alkaline phosphatase-modified binding aptamer, leading to a LoD of $1 \mathrm{nM}$. A similar approach was used by Zhang et al. [49] but using HRP as the amplifying label. DPV was used to obtain a LoD down to $20 \mathrm{nM}$. Lastly, Shen et al. [50] added rolling circle amplification (RCA) in addition to alkaline phosphatase amplification, and used DPV for detection. This dual amplification strategy strongly decreased the detection limit down to $1 \mathrm{nM}$.

All these results are summarized in Table 3. Due to very few examples of Ab sensors for cocaine, a comparison between Abs and aptamers cannot be objective. As for other targets, nanostructuration of the electrodes led to a gain in terms of LoD, of one to three orders of magnitude. Again, as for antibiotics, enzymatic amplifications applied to aptamers do not bring lower detection limits, as it could be expected. Lastly, even if it is an obvious observation, these results show that the sensitivity largely depends on the affinity of the aptamer for its target: the lowest LoD were obtained with aptamers having low $\mathrm{K}_{\mathrm{D}}$. 
Table 3. Figures of merit of selected immunosensors and aptasensors for detection of cocaine.

\begin{tabular}{cccc}
\hline Bioreceptors & LoD & Transduction and Analytical Methods & Ref. \\
\hline $\mathrm{Ab}$ & $380 \mathrm{pM}$ & AlkP-Ab/CV & {$[35]$} \\
$\mathrm{Ab}$ & $0.1 \mu \mathrm{M}$ & HRP-Ab/CV & {$[36]$} \\
$\mathrm{Ab}$ & $33 \mathrm{fM}$ & SAM/EIS & {$[37]$} \\
Aptamer & $10 \mu \mathrm{M}$ & MB-labeled/CV & {$[39]$} \\
Aptamer & $1 \mu \mathrm{M}$ & Two-strand aptamer/SWV & {$[40]$} \\
Aptamer & $1 \mu \mathrm{M}$ & PtNPs-aptamer $/ \mathrm{H}_{2} \mathrm{O}_{2} / \mathrm{CV}$ & {$[41]$} \\
Aptamer & $0.1 \mu \mathrm{M}$ & Label-free/Two-strand aptamer/CV & {$[42]$} \\
Aptamer & $50 \mathrm{nM}$ & Two-strand aptamer/QDs & {$[43]$} \\
Aptamer & $1 \mathrm{nM}$ & Two-strand aptamer/QDs & {$[44]$} \\
Aptamer & $100 \mathrm{nM}$ & Two-strand aptamer/EIS/[Fe $\left.(\mathrm{CN})_{6}\right]^{3-/ 4-}$ & {$[45]$} \\
Aptamer & $100 \mathrm{pM}$ & Two-strand aptamer/AuNPs/DPV/[Fe $\left.(\mathrm{CN})_{6}\right]^{3-} / 4-$ & {$[46]$} \\
Aptamer & $150 \mathrm{pM}$ & Two-strand aptamer/AgNPs/CV/riboflavin & {$[47]$} \\
Aptamer & $1 \mathrm{nM}$ & Two-strand aptamer/AlkP/CV & {$[48]$} \\
Aptamer & $20 \mathrm{nM}$ & Two-strand aptamer/HRP/CV & {$[49]$} \\
Aptamer & $1 \mathrm{nM}$ & RCA/AlkP/DPV & {$[50]$} \\
\hline
\end{tabular}

\subsection{Ochratoxin A}

A toxin is a poisonous substance produced by living cells or organisms. Toxins can be small organic molecules, peptides, or proteins. The most studied toxin in electrochemical biosensors is ochratoxin A (Figure 10). It is one of the most abundant food-contaminating mycotoxins.

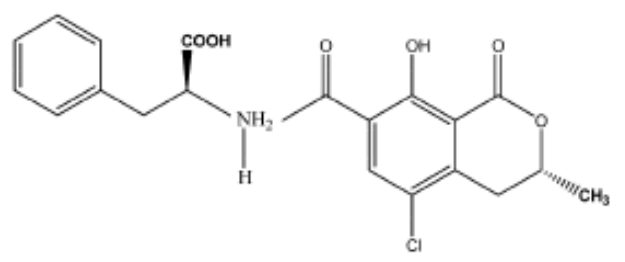

Figure 10. Structure of ochratoxin A (OTA).

\subsubsection{Antibodies}

Prieto-Simon et al. described, in 2008 [51], two indirect electrochemical competitive enzyme-linked immunosorbent assays (ELISA) for ochratoxin A (OTA). Performances of polyclonal (pAb) and monoclonal $(\mathrm{mAb})$ antibodies against OTA were compared, showing at least one order of magnitude higher affinity values when working with $\mathrm{mAb}$. Alkaline phosphatase (AlkP) and horseradish peroxidase (HRP)-labeled secondary antibodies were evaluated. Similar limits of detection of 0.7 and $0.3 \mathrm{ng} \cdot \mathrm{mL}^{-1}(0.8 \mathrm{nM})$ were obtained for HRP- and AlkP-labeled immunosensors, respectively. Later, in 2009, Radi et al. [52] described an electrochemical immunosensor for detection of OTA on screen-printed gold electrodes modified by electroreduction of 4-nitrophenyl diazonium salts and anti-OTA. A competition between OTA and HRP-labeled OTA (OTA-HRP) for the immobilized antibodies was held. The activity of the bound OTA-HRP was electrochemically measured by chronoamperometry using 3,3,5,5-tetramethylbenzidine (TMB) as substrate. A LoD of $12 \mathrm{ng} \cdot \mathrm{mL}^{-1}(30 \mathrm{nM})$ was obtained. The same authors [53] also investigated a similar architecture using EIS, with a LoD of $0.5 \mathrm{ng} \cdot \mathrm{mL}^{-1}$ $(1.3 \mathrm{nM})$.

Zamfir et al. described a label-free immunosensor based on magnetic nanoparticles for ochratoxin A [54]. The OTA antibodies were attached to these magnetic nanoparticles (MBs) and afterwards immobilized on a gold electrode pretreated with bovine serum albumin (BSA) under a magnetic field. The impedance variations due to the specific antibody-OTA interactions were correlated with the OTA concentration in the samples. The increase in electron transfer resistance was proportional to the concentration of OTA on a linear range between 0.01 and $5 \mathrm{ng} \cdot \mathrm{mL}^{-1}(25 \mathrm{pM}-13 \mathrm{nM})$. 
An indirect competitive enzyme-linked immunosorbent assay format was also constructed by immobilizing ochratoxin A on gold electrodes [55]. Electrochemical detection was performed by chronoamperometry using TMB and hydrogen peroxide with HRP as label. A LoD of $0.05 \mu \mathrm{g} \cdot \mathrm{L}^{-1}$ (0.12 nM) was achieved.

Additionally, boron doped diamond (BDD) was employed [56] for sensitive immunodetection of ochratoxin A using EIS. Abs were grafted through diazonium functionalization. The increase in electron-transfer resistance presented a sigmoidal shape versus log concentration of OTA, with a dynamic range between $7 \mathrm{pg} \cdot \mathrm{mL}^{-1}$ and $25 \mathrm{ng} \cdot \mathrm{mL}^{-1}$. A LoD of $7 \mathrm{pg} \cdot \mathrm{mL}^{-1}$ (17 $\mathrm{pM}$ ) was obtained. These good results could be attributed to the low background and capacitive currents allowed by BDD compared to other more classical electrode materials.

Lastly, a label-free photoelectrochemical sensor was recently reported by Yang et al. [57], by assembly of $\mathrm{CdSe}$ nanoparticles on $\mathrm{TiO}_{2}$ electrodes. Ascorbic acid (AA) was used as an electron donor for scavenging photogenerated holes under visible-light irradiation. The photocurrent response of the CdSe NPs-modified electrode was significantly enhanced as a result of the band alignment of CdSe and $\mathrm{TiO}_{2}$ in electrolyte. OTA antibodies were immobilized on CdSe. Even if these values cannot strictly be compared to the previous ones because the transduction mechanism is not of the same nature, one may underline the good sensitivity of this technique, with a LoD of $2 \mathrm{pg} \cdot \mathrm{mL}^{-1}(5 \mathrm{pM})$ and a linear dependence with OTA concentration from $10 \mathrm{pg} \cdot \mathrm{mL}^{-1}$ to $50 \mathrm{ng} \cdot \mathrm{mL}^{-1}$.

\subsubsection{Aptamers}

Aptamers were also frequently reported in the literature, for ochratoxin A detection. A first electrochemical platform was described in 2010 using the DNA sequence 5'-GAT CGG GTG TGG GTG GCG TAA AGG GAG CAT CGG ACA-3' as aptamer probe [58]. In this article, the aptamer was immobilized on the surface of a glassy carbon electrode treated with $\mathrm{PCl}_{5}$-activated sulfonic acid groups able to bind amino-modified DNA strands. These primary strands were then sandwiched with two other DNA strands carrying methylene blue (MB) as redox label. Binding of the OTA target to the aptamer disassembled the DNA strands and lowered the MB redox current. The low LoD (30 pg. $\mathrm{mL}^{-1}$, i.e., $80 \mathrm{pM}$ ) could be attributed to the functionalization strategy (direct coupling of the DNA strands on the electrode without any intermediate bulky groups). One year later, a Langmuir-Blodgett (polyaniline (PANI)-stearic acid (SA)) impedimetric OTA aptasensor was developed by Prabhakar et al. [59]. The DNA aptamer was covalently immobilized onto the LB monolayer deposited onto ITO plates. The dissociation constant $\left(\mathrm{K}_{\mathrm{D}}\right)$ was found to be $c a .0 .8 \times 10^{-7} \mathrm{M}$ and the LoD was $0.1 \mathrm{ng} \cdot \mathrm{mL}^{-1}(0.25 \mathrm{nM})$, i.e., higher than with the direct coupling strategy of Kuang et al.

Tong et al., in 2011 [60], described an original signal-on aptasensor based on exonuclease-catalyzed target recycling. To construct the aptasensor, a Fc-labeled probe DNA (5'-Fc-AAA GAT CGG GTG TGG GTG GCG TAA AGG GAG CAT CGG ACA-3'-SH), carrying the Fc label at its 5'-distal end was immobilized on Au electrode through $3^{\prime}$-thiol chemisorption, and hybridized with the complementary ochratoxin A aptamer. In the presence of ochratoxin A, formation of the complex resulted in the transformation of the probe DNA into a hairpin structure where the Fc group comes close to the electrode surface, therefore producing a current increase (signal-on). OTA was then decomplexed by the use of the exonuclease, which digest the aptamer, so that OTA is recycled and can come again to bind to another aptamer. Due to the amplification step, this original method gave a LoD of $1 \mathrm{pg} \cdot \mathrm{mL}^{-1}$ (2.5 pM). Zhang et al. [61] described a sensor based on a similar hairpin-shaped aptamer and site-specific DNA cleavage of restriction endonuclease TaqaI, with HRP instead of Fc. In their approach, the endonuclease is able to cut DNA (and release HRP in solution, far from the electrode surface) when OTA is absent; if OTA is present, there is no hairpin structure, and, therefore, the TaqI is inactive and HRP can be used as enzymatic amplification label. Due to this amplification, the reported LoD was $0.4 \mathrm{pg} \cdot \mathrm{mL}^{-1}(1 \mathrm{pM})$. 
Lastly, Hayat et al. reported, in 2013 [62], a strategy for the fabrication of an electrochemical label-free (but needing a redox molecule diffusing in solution) aptasensor where long spacer chains of polyethyleneglycol were used to create diffusion channels for the redox probe, while aptamers acted as gate of the tunnels, depending on their conformation. The LoD was $0.12 \mathrm{ng} \cdot \mathrm{L}^{-1}(0.3 \mathrm{pM})$. The aptamer sequence was the same as Tong et al.

\subsubsection{Peptides}

Even though it has not yet been applied to electrochemical sensors, peptides were also described in a few works as a probe for ochratoxin A. Indeed, Bazin et al. [63] reported in 2013 the peptide NF04 (12-mer sequence: N'-Lys-Cys-Cys-Lys-Tyr-Tyr-Lys-Arg-Asn-Met-Tyr-Val-C') for specific binding to ochratoxin A, which was evaluated using a peptide-based ELISA assay. Heurich et al., described a computational approach to design peptide ligands for Ochratoxin A [64]. Two peptides were identified: N'-Cys-Ser-Ile-Val-Glu-Asp-Gly-Lys-C' (octapeptide) and N'-Gly-Pro-Ala-Gly-Ile-Asp-Gly-Pro-Ala-Gly-Ile-Arg-Cys-C' (13-mer). SPR analysis confirmed that the peptides bind to ochratoxin A with KD values of 10 to $15 \mu \mathrm{M}$. More recently, Solerai et al. [65] reported another peptide conjugated chitosan foam for detection of OTA using enzymatic chemiluminescence. There is therefore no reason for electrochemical OTA sensors based on peptide probes not to appear in the literature in the forthcoming years.

All these results are summarized in Table 4. It appears that OTA sensors are generally more sensitive than for other targets, in the $\mathrm{pM}$ range, for both immunologic and aptamer approaches.

Table 4. Figures of merit of selected immunosensors and aptasensors for ochratoxin A.

\begin{tabular}{cccr}
\hline Bioreceptors & LoD & Transduction and Analytical Methods & Reference \\
\hline $\mathrm{Ab}$ & $0.8 \mathrm{nM}$ & AlkP- or HRP-Ab/CV & {$[51]$} \\
$\mathrm{Ab}$ & $30 \mathrm{nM}$ & $\mathrm{HRP} / \mathrm{TMB} /$ chronoamperometry & {$[52]$} \\
$\mathrm{Ab}$ & $1.3 \mathrm{nM}$ & $\mathrm{HRP} / \mathrm{TMB} / \mathrm{EIS}$ & {$[53]$} \\
$\mathrm{Ab}$ & $25 \mathrm{pM}$ & $\mathrm{MBs} / \mathrm{EIS}$ & {$[54]$} \\
$\mathrm{Ab}$ & $0.12 \mathrm{nM}$ & $\mathrm{HRP} / \mathrm{TMB} / \mathrm{EIS}$ & {$[55]$} \\
$\mathrm{Ab}$ & $17 \mathrm{pM}$ & $\mathrm{BDD} / \mathrm{EIS}$ & {$[56]$} \\
$\mathrm{Ab}$ & $5 \mathrm{pM}$ & $\mathrm{CdSe} / \mathrm{TiO} / \mathrm{PEC}$ & {$[57]$} \\
Aptamer & $80 \mathrm{pM}$ & Multiple stem $/ \mathrm{MB}-\mathrm{DNA} / \mathrm{CV}$ & {$[58]$} \\
Aptamer & $0.25 \mathrm{nM}$ & LB/PANI/EIS & {$[59]$} \\
Aptamer & $2.5 \mathrm{pM}$ & Fc-labeled aptamer/exonuclease/CV & {$[60]$} \\
Aptamer & $1 \mathrm{pM}$ & HRP-labeled aptamer/exonuclease/CV & {$[61]$} \\
Aptamer & $0.3 \mathrm{pM}$ & Fe(CN) $)^{3-/ 4-/ E I S}$ & {$[62]$} \\
\hline
\end{tabular}

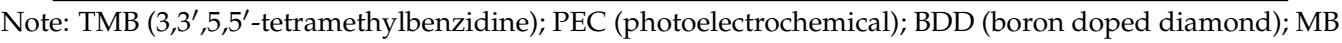
(methylene blue); LB (Langmuir Blodgett); PANI (polyaniline).

\subsection{Estradiol}

\subsubsection{Antibodies}

Estradiol (E2, Figure 11) immunosensors were extensively reported in the literature. In 1998, Padeste et al. [66] reported an amperometric immunosensor for estradiol using microperoxidase MP-11 antibody conjugates for amplification. However, in this preliminary work, the authors provided neither LoD nor sensitivity. Five year later, in 2003, Kuramitz et al. [67] described a 17 $\beta$-estradiol-modified electrode for non-labeled immunoassay. When the antibody was bound to the estradiol self-assembled monolayer on the gold electrode surface, they observed a decrease of the electroactivity of the redox probes added in solution (BQ or $\mathrm{Fe}(\mathrm{CN})_{6}{ }^{3-/ 4-}$ ), attributed to the steric hindrance between the antibody on the electrode surface and the redox marker. The authors detected $17 \beta$-estradiol, $17 \beta$-estradiol-6-one (1,3,5-estratriene-3,17 $\beta$-diol-6-one 6-O-carboxymethyloxime) and diethylstilbestrol using competition for the antibody between the analyte in solution and $17 \beta$-estradiol immobilized on the electrode 
surface, and found that the affinities ranked as follow: $17 \beta$-estradiol-6-one $>17 \beta$-estradiol $>$ DES. The LoD for $17 \beta$-estradiol was $c a$. $0.1 \mathrm{nM}$ (the KD was estimated around $10^{-7} \mathrm{M}$ ).

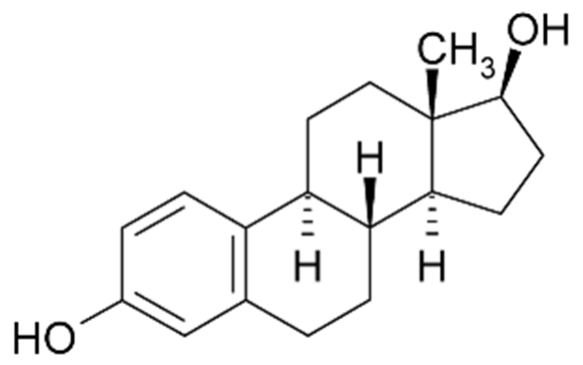

Figure 11. Structure of estradiol (E2).

In 2005, Pemberton et al. [68] investigated an electrochemical immunosensor for estradiol on carbon SPE electrodes. A competitive immunoassay was performed using an AlkP-labeled estradiol conjugate. Electrochemical measurements were performed using differential pulse voltammetry (DPV) following the production of 1-naphthol from 1-naphthyl phosphate. The LoD was of $50 \mathrm{pg} \cdot \mathrm{mL}^{-1}$ (0.2 nM). In 2006, Butler et al. [69] also reported very similar work. The sensor detected 17-beta-estradiol in an environmentally relevant range with a LoD of $0.25 \mathrm{pg} \cdot \mathrm{mL}^{-1}(0.9 \mathrm{pM})$. The same year, Volpe et al. [70] reported a similar work with a LoD of $40 \mathrm{pg} \cdot \mathrm{mL}^{-1}(0.15 \mathrm{nM})$ in bovine serum.

As for the other analytes, nanostructuration of the electrodes improved sensitivity and LoD. For example, Liu et al. (2009) [71] reported the use of AuNPs immobilized on gold electrodes in order to increase the surface area and therefore to improve sensitivity. For amplification, they used a HRP-labeled 17 beta-estradiol conjugate and benzoquinone (BQ) as redox reporter. They reported a LoD of $6 \mathrm{pg} \cdot \mathrm{mL}^{-1}(20 \mathrm{pM})$. In 2010, the same authors compared SWV and EIS on a SAM-modified Au electrode carrying AuNPs vertical bar thiolated protein G-scaffold to facilitate the immobilization of an enhanced quantity of an almost uprightly aligned anti-estradiol capture antibody [72]. They used $\mathrm{Fe}(\mathrm{CN})_{6}{ }^{3-/ 4-}$ as redox probe. They obtained a LoD of $18 \mathrm{pg} \cdot \mathrm{mL}^{-1}(65 \mathrm{pM})$ for SWV, and $26 \mathrm{pg} \cdot \mathrm{mL}^{-1}$ for EIS (95 pM), e.g., not better than for their previous work. Again using nano/microstructuration, Martinez et al. [73] developed a competitive direct immunoassay using magnetic microspheres and an estradiol-HRP conjugate. The detection of estradiol was carried out using a competitive direct immunoassay format using anti-estradiol polyclonal Abs immobilized on 3-aminopropyl-modified magnetic microspheres. Estradiol present in the sample competed with an estradiol-HRP conjugate for the immobilized antibody. The current obtained from the enzymatic reaction was inversely proportional to the amount of estradiol in the sample. The LoD was $0.32 \mathrm{ng}$ L-1 (ca. $1 \mathrm{pM}$ ).

More recently, in 2012, Kim et al. [74] described an impedimetric sensor by immobilizing a monolayer of estrogen receptor-alpha on Au electrodes. The binding of $17 \beta$-estradiol increased the electron-transfer resistance of the electrode which was directly monitored by EIS in the presence of $\mathrm{Fe}(\mathrm{CN})_{6}{ }^{3-/ 4-}$. Despite the small size of estradiol compared to that of the immobilized antibody, the authors reported a $\mathrm{K}_{\mathrm{D}}$ of $c a .5 \mathrm{pM}$ and a LoD of $c a .0 .1 \mathrm{pM}$. Liu et al. [75] published an original copper monolayer-based sensor to construct a $\mathrm{Cu}$ /vertical bar protein $\mathrm{G}$ immunosensor for 17 beta-estradiol. Copper minimized the non-specific adsorption of biological molecules on the immunosensor surface and enhanced the binding efficiency between immunosensor surface and protein G. SWV was employed to monitor the electrochemical reduction current of ferrocenemethanol; SWV current decreased with the increase of estradiol-BSA conjugate concentration. The LoD was $12 \mathrm{pg} \cdot \mathrm{mL}^{-1}(45 \mathrm{pM})$.

In 2012, Ojeda et al., described a more classical approach [76] based on the surface modification of a carbon SPE with grafted p-aminobenzoic acid (PABA), followed by covalent binding of streptavidin and immobilization of biotinylated anti-estradiol antibodies labeled with HRP. Hydroquinone was used as redox mediator. A LoD of $0.77 \mathrm{pg} \cdot \mathrm{mL}^{-1}(2.8 \mathrm{pM})$ was achieved. Kanso et al. [77] described two 
methods using MBs onto which synthetic estrogen derivatives were bound. Using a classical primary antibody and a HRP-labeled secondary antibody, SWV was used for detection of the enzyme product, with LoDs between 1 and $10 \mathrm{ng} \cdot \mathrm{L}^{-1}$ (3.6-36 pM) (Figure 12).

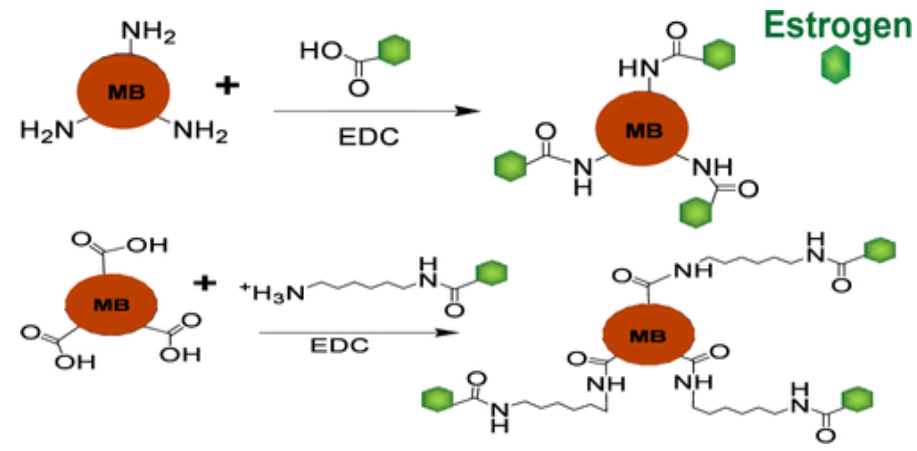

(A)

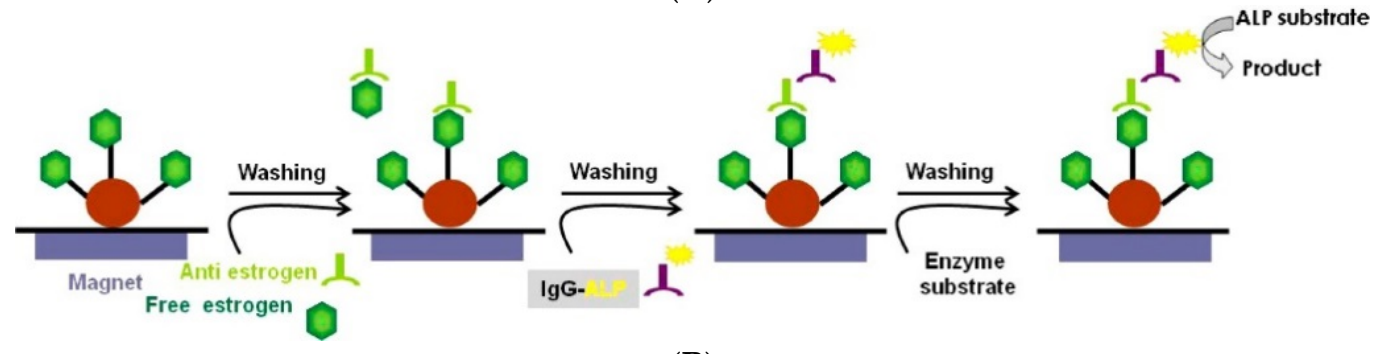

(B)

Figure 12. Strategy for (A) estrogen functionalization with magnetic beads; (B) indirect competitive assay for both colorimetric and electrochemical detection based on functionalized MBs. Reproduced from [77] with permission.

Chaisuwan et al. described also an original procedure [78] using estradiol-modified CdSe quantum dots (QDs). A bismuth-coated electrode was used for detecting the cadmium ions $\left(\mathrm{Cd}^{2+}\right)$ released during the acid dissolution of the QDs, after the recognition step that occurred in solution. The LoD was ca. $52 \mathrm{pg} \cdot \mathrm{mL}^{-1}(0.2 \mathrm{nM})$.

Still using nanoparticles, Li et al. [79] described an estradiol immunosensor based on graphene-polyaniline (GR-PANI) composites and graphene oxide (GO). HRP-GO-antibody conjugates were used to improve sensitivity, through a competitive immunoassay. The LoD was of $0.02 \mathrm{ng} \cdot \mathrm{mL}^{-1}$ (75 pM). Very recently (2015), again using nanostructures, Zhang et al. [80] reported a sensor using $\mathrm{Cu}_{2} \mathrm{~S}$ nanostructures as labels. $\mathrm{Cu}_{2} \mathrm{~S}$ NPs were covalently conjugated to BSA-estradiol. Even without using enzyme-label and acid dissolution, the $\mathrm{Cu}_{2} \mathrm{~S}$ generated an intense electrochemical SWV signal giving a LoD of $7.5 \mathrm{pg} \cdot \mathrm{mL}^{-1}(28 \mathrm{pM})$. The same authors [81] described a graphene-modified electrode modified with mesoporous $\mathrm{Fe}_{3} \mathrm{O}_{4}$ and loaded with $\mathrm{Pb}^{2+}$ or $\mathrm{Cd}^{2+}$ cations and estradiol antibodies. In this case, square wave adsorptive stripping voltammetry (SWASV) was used, in order to detect $\mathrm{Pb}^{2+}$ or $\mathrm{Cd}^{2+}$. SWASV peak currents were proportional to the concentrations of estradiol down to a LoD of $0.015 \mathrm{pg} \cdot \mathrm{mL}^{-1}$ (55 fM). Lastly, Jimena et al. [82] developed an immunosensor by immobilization of the anti-17 beta-estradiol monoclonal antibody on an Au disk modified with AuNPs on a cysteamine SAM. The limit of detection was $0.84 \mathrm{pg} \cdot \mathrm{mL}^{-1}(3 \mathrm{pM})$. To conclude this section and as already remarked in Section 2.1 concerning antibiotics, the most pertinent strategy to reach the lowest limits of detection is to use adsorptive stripping methods [78,81]. 


\subsubsection{Aptamers}

Comparatively, aptamer-based estradiol sensors were less reported than their immunosensor counterparts and their use appeared more recently. Olowu et al. [83] described in 2010 an electrochemical DNA aptasensor for 17-beta-estradiol based on poly(3,4-ethylenedioxythiophene) (PEDOT) doped with AuNPs. Streptavidin was covalently attached to the electrode and the aptamer immobilized via streptavidin-biotin interaction. The electrochemical signal generated from the aptamer-target molecule interaction was monitored by standard $\mathrm{CV}$ and $\mathrm{SWV}$ using $\mathrm{Fe}(\mathrm{CN})_{6}{ }^{3-/ 4-}$ as redox probe. The signal observed showed a current decrease due to steric hindrance from the bound 17 beta-estradiol. The LoD was $0.1 \mathrm{nM}$. In 2012, Lin et al. [84] reported also a conventional transduction approach based on EIS with Au electrodes modified by a thiolated aptamer. Upon formation of the estradiol/aptamer complex on the electrode surface, the interfacial electron transfer resistance (Ret) increased, with a detection limit of $2 \mathrm{pM}$. This Ret increased was explained by the fact that the negatively-charged aptamer probe hindered the electron transfer reaction of the redox probe $\mathrm{Fe}(\mathrm{CN})_{6}{ }^{3-/ 4-}$ on the Au electrode surface.

More recently, in 2014, Huang et al. [85] described a more original nanostructured sensor using flower-like vanadium disulfide, showing ordered nanosheets of several nanometers of thickness onto which the aptamers were immobilized. Very classically, $\mathrm{Fe}(\mathrm{CN})_{6}{ }^{3-/ 4-}$ was used as a diffusing redox probe and DPV was used to sense change in apparent diffusion coefficient when 17-beta-estradiol is associated with the grafted aptamers. A detection limit of $c a .1 \mathrm{pM}$ was reported. Again exploiting nanostructuration, Ke et al. [86] reported a dendritic gold microstructure immobilized on boron doped diamond (BDD) electrode. Estradiol aptamers were immobilized on the surface of the dendritic $\mathrm{Au} / \mathrm{BDD}$ electrode through Au-S interaction. Once estradiol reacts with aptamers, it enlarges the interfacial electron transfer resistance (sensed by EIS, again using the redox probe $\left.\mathrm{Fe}(\mathrm{CN})_{6}{ }^{3-} / \mathrm{Fe}(\mathrm{CN})_{6}{ }^{4-}\right)$ on the electrode surface thus cause the increase of impedance) down to a LoD of $5 \mathrm{fM}$ of estradiol. In 2015, Zhu et al. [87] reported a nanoporous conducting polymer electrode whose surface potential, modified upon interaction between estradiol and its aptamer, was still probed via EIS using $\mathrm{Fe}(\mathrm{CN})_{6}{ }^{3-/ 4-}$ as redox probe. Transduction was explained by the redistribution of negative charges in the electrode double-layer region when the aptamer adopts a folded conformation around the small neutral target molecule. The LoD was in the fM range. Additionally, in 2015, Fan et al. [88] used nickel hexacyanoferrate NPs as signaling probe, immobilized on the electrode. AuNPs were put on the $\mathrm{NiFe}(\mathrm{CN})_{6} \mathrm{NPs}$, and the thiolated aptamer was immobilized. Upon formation of estradiol-aptamer complex, the interfacial electron transfer reaction (still probed via EIS using $\left.\mathrm{Fe}(\mathrm{CN})_{6}{ }^{3-/ 4-}\right)$ of the probe was lowered, resulting in the decrease of the electrochemical signal. The LoD was ca. 1 pM.

At last, Jimenez et al. [89] described the selection of aptamers having dissociation constants for estradiol in the low $\mathrm{nM}$ range (17 $\mathrm{nM}$ for the best one). They described an EIS aptasensor based on the conformational change of the aptamer immobilized on a gold electrode by self-assembly. It was shown that the signal of the $\mathrm{Fe}(\mathrm{CN})_{6}{ }^{3-/ 4-}$ redox probe was optimized upon hybridization of the aptamer with a short complementary sequence at some specific sites, which was attributed to the more significant conformational change of the aptamer/DNA duplex than the single-stranded aptamer upon binding with the target. The LoD was $0.90 \mathrm{ng} \cdot \mathrm{mL}^{-1}(3 \mathrm{nM})$.

All these results are summarized in Table 5. LoDs appear to be lower for estradiol than for the other targets dealt with in this review. Conversely to pollutants or other toxic small organic molecules, antibodies are available and lead to low LoDs, even if aptamers allow to obtain the lower ones (for similar transduction methods). If we compared LoD for a same probe, similarly to the others targets discussed above, the enzyme-amplified strategy applied with aptamer probes do not lead to significant improvements; this a obviously not the case for antibodies, for which enzyme-labelling has long proven its efficiency. Concerning the sensing strategies used with aptamers, EIS coupled to the $\mathrm{Fe}(\mathrm{CN})_{6}{ }^{3-/ 4-}$ redox probe is dominant. Efforts could be made to improve this step. 
Table 5. Figures of merit of selected immunosensors and aptasensors for detection of estradiol.

\begin{tabular}{|c|c|c|c|}
\hline Bioreceptors & LoD & Transduction and Analytical Methods & Reference \\
\hline $\mathrm{Ab}$ & $0.1 \mathrm{nM}$ & $\mathrm{SAM} / \mathrm{BQ} / \mathrm{CV}$ & [67] \\
\hline $\mathrm{Ab}$ & $0.2 \mathrm{nM}$ & AlkP-estradiol/DPV & [68] \\
\hline $\mathrm{Ab}$ & $0.9 \mathrm{pM}$ & AlkP-estradiol/amperometry & [69] \\
\hline $\mathrm{Ab}$ & $0.15 \mathrm{nM}$ & AlkP-estradiol/amperometry & [70] \\
\hline $\mathrm{Ab}$ & 20 pM & $\mathrm{AuNPs} / \mathrm{HRP} / \mathrm{BQ} / \mathrm{CV}$ & [71] \\
\hline $\mathrm{Ab}$ & $65 \mathrm{pM}$ & AuNPs/Protein G/[Fe(CN) $\left.{ }_{6}\right]^{3-/ 4-} / \mathrm{SWV}$ & [72] \\
\hline $\mathrm{Ab}$ & $95 \mathrm{pM}$ & AuNPs/Protein G/[Fe $\left.(\mathrm{CN})_{6}\right]^{3-/ 4-} /$ EIS & [72] \\
\hline $\mathrm{Ab}$ & $1 \mathrm{pM}$ & MBs/HRP-estradiol & [73] \\
\hline $\mathrm{Ab}$ & $0.1 \mathrm{pM}$ & HRP-estradiol/Catechol/CV & [74] \\
\hline $\mathrm{Ab}$ & $45 \mathrm{pM}$ & Protein G/Fc-MeOH/SWV & [75] \\
\hline $\mathrm{Ab}$ & $2.8 \mathrm{pM}$ & $\mathrm{PABA} / \mathrm{BQ}$ & [76] \\
\hline $\mathrm{Ab}$ & $3.6 \mathrm{pM}$ & MBs/AlkP- $\alpha \operatorname{IgG} / \mathrm{SWV}$ & [77] \\
\hline $\mathrm{Ab}$ & $0.2 \mathrm{nM}$ & CdSe QDs/dissolution (SWASV) & [78] \\
\hline $\mathrm{Ab}$ & $75 \mathrm{pM}$ & Graphene/HRP-GO & [79] \\
\hline $\mathrm{Ab}$ & $28 \mathrm{pM}$ & $\mathrm{Cu}_{2} \mathrm{SNPs} / \mathrm{CV}$ & [80] \\
\hline $\mathrm{Ab}$ & $55 \mathrm{fM}$ & $\mathrm{Pb}^{2+}, \mathrm{Cd}^{2+} /$ porous $\mathrm{Fe}_{3} \mathrm{O}_{4} /$ SWASV & [81] \\
\hline $\mathrm{Ab}$ & $3 \mathrm{pM}$ & AuNPs & [82] \\
\hline Aptamer & $0.1 \mathrm{nM}$ & PEDOT/AuNPs/Biot-Avidin/[Fe $\left.(\mathrm{CN})_{6}\right]^{3-/ 4-} / \mathrm{CV}-\mathrm{SWV}$ & [83] \\
\hline Aptamer & $2 \mathrm{pM}$ & $\mathrm{SAM} / \mathrm{Au} /\left[\mathrm{Fe}(\mathrm{CN})_{6}\right]^{3-/ 4-} / \mathrm{EIS}$ & [84] \\
\hline Aptamer & $1 \mathrm{pM}$ & $\mathrm{VS}_{2} /\left[\mathrm{Fe}(\mathrm{CN})_{6}\right]^{3-/ 4-} / \mathrm{DPV}$ & [85] \\
\hline Aptamer & $5 \mathrm{fM}$ & $\mathrm{Au} / \mathrm{BDD} /\left[\mathrm{Fe}(\mathrm{CN})_{6}\right]^{3-/ 4-} / \mathrm{EIS}$ & [86] \\
\hline Aptamer & $1 \mathrm{fM}$ & Nanoporous electrode/[Fe $\left.(\mathrm{CN})_{6}\right]^{3-/ 4-} /$ EIS & [87] \\
\hline Aptamer & $1 \mathrm{pM}$ & $\left.\mathrm{Ni}^{3+}, \mathrm{Fe}(\mathrm{CN})_{6}\right]^{3-} / \mathrm{AuNPs}$ & [88] \\
\hline Aptamer & $3 \mathrm{nM}$ & $\mathrm{SAM} / \mathrm{Au} /\left[\mathrm{Fe}(\mathrm{CN})_{6}\right]^{3-/ 4-} / \mathrm{EIS}$ & [89] \\
\hline
\end{tabular}

Note: BQ (benzoquinone); Fc-MeOH (ferrocenemethanol); PABA (p-aminobenzoic acid); SWASV (square wave adsorptive stripping voltammetry).

\section{Conclusions and Perspectives}

Electrochemical immunosensors and aptasensors for organic molecules have been significantly reported in the literature since the mid-2000s, whereas peptide sensors remain confidential at this time. Limits of detections are generally two to three orders of magnitude lower for immunosensors than for aptasensors due to the highest affinities of antibodies. No significant progresses have been made to improve these affinities, but transduction schemes were improved instead, which led to a regular LoD improvement corresponding to $c a$. five orders of magnitude over these last 10 years.

If we look more closely to each target molecule discussed in this review, one sees that no significant progresses was made for antibiotics, for which immunosensors are still the most efficient compared to aptasensors, with an average LoD of $c a \cdot 10^{-10} \mathrm{M}$ versus $10^{-8} \mathrm{M}$, respectively. There are very few immunosensors for cocaine, whereas aptasensors, which appeared in 2006, are frequently reported and show an improvement of their LoD of five order of magnitudes over the last 10 years. Concerning ochratoxin A, there is no difference between immuno- and apta-sensors in terms of limit of detection, which progressed by two to three orders of magnitude over the last 10 years. Lastly, concerning estradiol, there is no significant difference between immuno- and apta-sensors in terms of limit of detection, and very little improvement has been made since the first publications.

From the existing literature, we did not identify obvious parameters which could be used to predict affinities of captures probes (antibodies or aptamers) for a given target. As stressed above, generally speaking, antibodies still present higher affinity constants for their targets than aptamers. This not only leads to lower LoD, but also to a better specificity when targets are sensed in complex matrixes. However, aptamers are more pertinent than antibodies when enantioselectivity is necessary, which is particularly pertinent for drug analysis.

Acknowledgments: Shihui Shi thanks China Scholarship Council for a PhD grant. 
Conflicts of Interest: The authors declare no conflicts of interest.

\section{References}

1. Sarma, V.R.; Silverton, E.W.; Davies, D.R.; Terry, W.D. The three-dimensional structure at 6 A resolution of a human gamma Gl immunoglobulin molecule. J. Biol. Chem. 1971, 246, 3753-3759. [PubMed]

2. Silverton, E.W.; Navia, M.A.; Davies, D.R. Three-dimensional structure of an intact human immunoglobulin. Proc. Natl. Acad. Sci. USA 1977, 74, 5140-5144. [CrossRef] [PubMed]

3. Antibodies-Online. Avaible online: http:/ /xww.antibodies-online.com (accessed on 26 February 2016).

4. Mascini, M.; Palchetti, I.; Tombelli, S. Nucleic Acid and Peptide Aptamers: Fundamentals and Bioanalytical Aspects. Angew. Chem. Int. Ed. 2012, 51, 1316-1332. [CrossRef] [PubMed]

5. Garifallou, G.Z.; Tsekenis, G.; Davis, F.; Higson, S.P.J.; Millner, P.A.; Pinacho, D.G.; Sanchez-Baeza, F.; Marco, M.P.; Gibson, T.D. Labeless immunosensor assay for fluoroquinolone antibiotics based upon an AC impedance protocol. Anal. Lett. 2007, 40, 1412-1422. [CrossRef]

6. Ionescu, R.E.; Jaffrezic-Renault, N.; Bouffier, L.; Gondran, C.; Cosnier, S.; Pinacho, D.G.; Marco, M.P.; Sanchez-Baeza, F.J.; Healy, T.; Martelet, C. Impedimetric immunosensor for the specific label free detection of ciprofloxacin antibiotic. Biosens. Bioelectron. 2007, 23, 549-555. [CrossRef] [PubMed]

7. Giroud, F.; Gorgy, K.; Gondran, C.; Cosnier, S.; Pinacho, D.G.; Marco, M.P.; Sánchez-Baeza, F.J. Impedimetric immunosensor based on a polypyrrole-antibiotic model film for the label-free picomolar detection of ciprofloxacin. Anal. Chem. 2009, 81, 8405-8409. [CrossRef] [PubMed]

8. Wu, C.C.; Lin, C.H.; Wang, W.S. Development of an enrofloxacin immunosensor based on label-free electrochemical impedance spectroscopy. Talanta 2009, 79, 62-67. [CrossRef] [PubMed]

9. Zang, S.; Liu, Y.; Lin, M.; Kang, J.; Sun, Y.; Lei, H. A dual amplified electrochemical immunosensor for ofloxacin: Polypyrrole film-Au nanocluster as the matrix and multi-enzyme-antibody functionalized gold nanorod as the label. Electrochim. Acta 2013, 90, 246-253. [CrossRef]

10. Zacco, E.; Adrian, J.; Galve, R.; Marco, M.P.; Alegret, S.; Pividori, M.I. Electrochemical magneto immunosensing of antibiotic residues in milk. Biosens. Bioelectron. 2007, 22, 2184-2191. [CrossRef] [PubMed]

11. Centi, S.; Stoica, A.I.; Laschi, S.; Mascini, M. Development of an Electrochemical Immunoassay Based on the Use of an Eight-Electrodes Screen-Printed Array Coupled with Magnetic Beads for the Detection of Antimicrobial Sulfonamides in Honey. Electroanalysis 2010, 22, 1881-1888. [CrossRef]

12. Conzuelo, A.F.; Gamella, M.; Campuzano, S.; Reviejo, A.J.; Pingarrón, J.M. Disposable amperometric magneto-immunosensor for direct detection of tetracyclines antibiotics residues in milk. Anal. Chim. Acta 2012, 737, 29-36. [CrossRef] [PubMed]

13. Conzuelo, F.; Campuzano, S.; Gamella, M.; Pinacho, D.G.; Reviejo, A.J.; Marco, M.P.; Pingarrón, J.M. Integrated disposable electrochemical immunosensors for the simultaneous determination of sulfonamide and tetracycline antibiotics residues in milk. Biosens. Bioelectron. 2013, 50, 100-105. [CrossRef] [PubMed]

14. Que, X.; Chen, X.; Fu, L.; Lai, W.; Zhuang, J.; Chen, G.; Tang, D. Platinum-catalyzed hydrogen evolution reaction for sensitive electrochemical immunoassay of tetracycline residues. J. Electroanal. Chem. 2013, 704, 111-117. [CrossRef]

15. Kim, Y.S.; Niazi, J.H.; Gu, M.B. Specific detection of oxytetracycline using DNA aptamer-immobilized interdigitated array electrode chip. Anal. Chim. Acta 2009, 634, 250-254. [CrossRef] [PubMed]

16. Kim, Y.J.; Kim, Y.S.; Niazi, J.H.; Gu, M.G. Electrochemical aptasensor for tetracycline detection. Bioprocess. Biosyst. Eng. 2010, 33, 31-37. [CrossRef] [PubMed]

17. Zhou, L.; Li, D.J.; Gai, L.; Wang, J.P.; Li, Y.B. Electrochemical aptasensor for the detection of tetracycline with multi-walled carbon nanotubes amplification. Sens. Actuators B Chem. 2012, 162, 201-208. [CrossRef]

18. Chen, D.; Yao, D.; Xie, C.; Liu, D. Development of an aptasensor for electrochemical detection of tetracycline. Food Control 2014, 42, 109-115. [CrossRef]

19. Shen, G.; Guo, Y.; Sun, X.; Wang, X. Electrochemical Aptasensor Based on Prussian Blue-Chitosan-Glutaraldehyde for the Sensitive Determination of Tetracycline. Nano-Micro Lett. 2014, 6, 143-152. [CrossRef]

20. De-los-Santos-Álvarez, N.; Lobo-Castañón, M.J.; Miranda-Ordieres, A.J.; Tuñón-Blanco, P. Modified-RNA aptamer-based sensor for competitive impedimetric assay of neomycin B. J. Am. Chem. Soc. 2007, 129, 3808-3809. [CrossRef] [PubMed] 
21. Rowe, A.A.; Miller, E.A.; Plaxco, K.W. Reagentless Measurement of Aminoglycoside Antibiotics in Blood Serum via an Electrochemical, Ribonucleic Acid Aptamer-Based Biosensor. Anal. Chem. 2010, 82, 7090-7095. [CrossRef] [PubMed]

22. Liu, J.; Wagan, S.; Morris, M.D.; Taylor, J.; White, R.J. Achieving Reproducible Performance of Electrochemical, Folding Aptamer-Based Sensors on Microelectrodes: Challenges and Prospects. Anal. Chem. 2014, 86, 11417-11424. [CrossRef] [PubMed]

23. González-Fernández, E.; de-los-Santos-Álvarez, N.; Lobo-Castañón, M.J.; Miranda-Ordieres, A.J.; Tuñón-Blanco, P. Aptamer-Based Inhibition Assay for the Electrochemical Detection of Tobramycin Using Magnetic Microparticles. Electroanalysis 2011, 23, 43-49. [CrossRef]

24. González-Fernández, E.; de-los-Santos-Álvarez, N.; Miranda-Ordieres, A.J.; Lobo-Castañón, M.J. Monovalent labeling system improves the sensitivity of aptamer-based inhibition assays for small molecule detection. Sens. Actuators B Chem. 2013, 182, 668-674. [CrossRef]

25. Zhu, Y.; Chandra, P.; Song, K.M.; Ban, C.; Shim, Y.B. Label-free detection of kanamycin based on the aptamer-functionalized conducting polymer/gold nanocomposite. Biosens. Bioelectron. 2012, 36, $29-34$. [CrossRef] [PubMed]

26. Daprà, J.; Lauridsen, L.H.; Nielsen, A.T.; Rozlosnik, N. Comparative study on aptamers as recognition elements for antibiotics in a label-free all-polymer biosensor. Biosens. Bioelectron. 2013, 43, 315-320. [CrossRef] [PubMed]

27. Ragavan, K.V.; Rastogi, N.K.; Thakur, M.S. Sensors and biosensors for analysis of bisphenol-A. TRAC Trend Anal. Chem. 2013, 52, 248-260. [CrossRef]

28. Rahman, M.A.; Shiddiky, M.J.A.; Park, J.S.; Shim, Y.B. An impedimetric immunosensor for the label-free detection of bisphenol A. Biosens. Bioelectron. 2007, 22, 2464-2470. [CrossRef] [PubMed]

29. Piao, M.H.; Noh, H.B.; Rahman, M.A.; Won, M.S.; Shim, Y.B. Label-Free Detection of Bisphenol A Using a Potentiometric Immunosensor. Electroanalysis 2008, 20, 30-37. [CrossRef]

30. Wang, X.; Reisberg, S.; Serradji, N.; Anquetin, G.; Pham, M.C.; Wu, W.; Dong, C.Z.; Piro, B. E-assay concept: Detection of bisphenol A with a label-free electrochemical competitive immunoassay. Biosens. Bioelectron. 2014, 53, 214-219. [CrossRef] [PubMed]

31. Xue, F.; Wu, J.J.; Chu, H.Q.; Mei, Z.L.; Ye, Y.K.; Liu, J.; Zhang, R.; Peng, C.F.; Zheng, L.; Chen, W. Electrochemical aptasensor for the determination of bisphenol A in drinking water. Microchim. Acta 2013, 180, 109-115. [CrossRef]

32. Zhou, L.; Wang, J.; Li, D.; Li, Y. An electrochemical aptasensor based on gold nanoparticles dotted graphene modified glassy carbon electrode for label-free detection of bisphenol A in milk samples. Food Chem. 2014, 162, 34-40. [CrossRef] [PubMed]

33. Yang, J.; Kim, S.E.; Cho, M.; Yoo, I.K.; Choe, W.S.; Lee, Y. Highly sensitive and selective determination of bisphenol-A using peptide-modified gold electrode. Biosens. Bioelectron. 2014, 61, 38-44. [CrossRef] [PubMed]

34. Kim, K.S.; Jang, J.R.; Choe, W.S.; Yoo, P.J. Electrochemical detection of Bisphenol A with high sensitivity and selectivity using recombinant protein-immobilized graphene electrodes. Biosens. Bioelectron. 2015, 71, 214-221. [CrossRef] [PubMed]

35. Bauer, C.G.; Eremenko, A.V.; Kühn, A.; Kürzinger, K.; Makower, A.; Scheller, F.W. Anal. Chem. 1998, 70, 4624-4630.

36. Suleiman, A.A.; Xu, Y.H. An amperometric immunosensor for cocaine. Electroanalysis 1998, 10, $240-243$. [CrossRef]

37. Yang, Y.; Pan, J.Y.; Hua, W.J.; Tu, Y.F. An approach for the preparation of highly sensitive electrochemical impedimetric immunosensors for the detection of illicit drugs. J. Electroanal. Chem. 2014, 726, 1-6. [CrossRef]

38. Ozkan, S.A.; Kauffmann, J.M.; Zuman, P. Electrochemical Biosensors for Drug Analysis. In Electroanalysis in Biomedical and Pharmaceutical Sciences; Springer: Verlag/Heidelberg, Germany, 2015; pp. 141-186.

39. Baker, B.R.; Lai, R.Y.; Wood, M.S.; Doctor, E.H.; Heeger, A.J.; Plaxco, K.W. An Electronic, Aptamer-Based Small-Molecule Sensor for the Rapid, Label-Free Detection of Cocaine in Adulterated Samples and Biological Fluids. J. Am. Chem. Soc. 2006, 128, 3138-3139. [CrossRef] [PubMed]

40. Zuo, X.; Xiao, Y.; Plaxco, K.W. High Specificity, Electrochemical Sandwich Assays Based on Single Aptamer Sequences and Suitable for the Direct Detection of Small-Molecule Targets in Blood and Other Complex Matrices. J. Am. Chem. Soc. 2009, 131, 6944-6945. [CrossRef] [PubMed] 
41. Golub, E.; Pelossof, G.; Freeman, R.; Zhang, H.; Willner, I. Electrochemical, Photoelectrochemical, and Surface Plasmon Resonance Detection of Cocaine Using Supramolecular Aptamer Complexes and Metallic or Semiconductor Nanoparticles. Anal. Chem. 2009, 81, 9291-9298. [CrossRef] [PubMed]

42. Du, Y.; Chen, C.; Yin, J.; Li, B.; Zhou, M.; Dong, S.; Wang, E. Solid-State Probe Based Electrochemical Aptasensor for Cocaine: A Potentially Convenient, Sensitive, Repeatable, and Integrated Sensing Platform for Drugs. Anal. Chem. 2010, 82, 1556-1563. [CrossRef] [PubMed]

43. Zhang, H.; Jiang, B.; Xiang, Y.; Zhang, Y.; Chai, Y.; Yuan, R. Aptamer/quantum dot-based simultaneous electrochemical detection of multiple small molecules. Anal. Chim. Acta 2011, 688, 99-103. [CrossRef] [PubMed]

44. Hua, M.; Li, P.; Li, L.; Huang, L.; Zhao, X.; Feng, Y.; Yang, Y. Quantum dots as immobilized substrate for electrochemical detection of cocaine based on conformational switching of aptamer. J. Electroanal. Chem. 2011, 662, 306-311. [CrossRef]

45. Zhang, D.W.; Zhang, F.T.; Cui, Y.R.; Deng, Q.P.; Krause, S.; Zhou, Y.L.; Zhang, X.X. A label-free aptasensor for the sensitive and specific detection of cocaine using supramolecular aptamer fragments/target complex by electrochemical impedance spectroscopy. Talanta 2012, 92, 65-71. [CrossRef] [PubMed]

46. Roushani, M.; Shahdost-fard, F. A highly selective and sensitive cocaine aptasensor based on covalent attachment of the aptamer-functionalized AuNPs onto nanocomposite as the support platform. Anal. Chim. Acta 2015, 853, 214-221. [CrossRef] [PubMed]

47. Roushani, M.; Shahdost-fard, F. A novel ultrasensitive aptasensor based on silver nanoparticles measured via enhanced voltammetric response of electrochemical reduction of riboflavin as redox probe for cocaine detection. Sens. Actuators B Chem. 2015, 207, 764-771. [CrossRef]

48. Jiang, B.; Wang, M.; Chen, Y.; Xie, J.; Xiang, Y. Highly sensitive electrochemical detection of cocaine on graphene/AuNP modified electrode via catalytic redox-recycling amplification. Biosens. Bioelectron. 2012, 32, 305-308. [CrossRef] [PubMed]

49. Zhang, D.W.; Sun, C.J.; Zhang, F.T.; Xu, L.; Zhou, Y.L.; Zhang, X.X. An electrochemical aptasensor based on enzyme linked aptamer assay. Biosens. Bioelectron. 2012, 31, 363-368. [CrossRef] [PubMed]

50. Shen, B.; Li, J.; Cheng, W.; Yan, Y.; Tang, R.; Li, Y.; Ju, H.; Ding, S. Electrochemical aptasensor for highly sensitive determination of cocaine using a supramolecular aptamer and rolling circle amplification. Microchim. Acta 2015, 182, 361-367. [CrossRef]

51. Prieto-Simon, B.; Campas, M.; Marty, J.L.; Noguer, T. Novel highly-performing immunosensor-based strategy for ochratoxin A detection in wine samples. Biosens. Bioelectron. 2008, 23, 995-1002. [CrossRef] [PubMed]

52. Radi, A.E.; Munoz-Berbel, X.; Cortina-Puig, M.; Marty, J.L. An electrochemical immunosensor for ochratoxin A based on immobilization of antibodies on diazonium-functionalized gold electrode. Electrochim. Acta 2009, 54, 2180-2184. [CrossRef]

53. Radi, A.E.; Munoz-Berbel, X.; Lates, V.; Marty, J.L. Label-free impedimetric immunosensor for sensitive detection of ochratoxin A. Biosens. Bioelectron. 2009, 24, 1888-1892. [CrossRef] [PubMed]

54. Zamfir, L.G.; Geana, I.; Bourigua, S.; Rotariu, L.; Bala, C.; Errachid, A.; Jaffrezic-Renault, N. Highly sensitive label-free immunosensor for ochratoxin A based on functionalized magnetic nanoparticles and EIS/SPR detection. Sens. Actuators B Chem. 2011, 159, 178-184. [CrossRef]

55. Heurich, M.; Abdul Kadir, M.K.; Tothill, I.E. An electrochemical sensor based on carboxymethylated dextran modified gold surface for ochratoxin A analysis. Sens. Actuators B Chem. 2011, 156, 162-168. [CrossRef]

56. Chrouda, A.; Sbartai, A.; Bessueille, F.; Renaud, L.; Maaref, A.; Jaffrezic-Renault, N. Electrically addressable deposition of diazonium functionalized antibodies on boron-doped diamond microcells for the detection of ochratoxin A. Anal. Methods 2015, 7, 2444-2451. [CrossRef]

57. Yang, J.; Gao, P.; Liu, Y.; Li, R.; Ma, H.; Du, B.; Wei, Q. Label-free photoelectrochemical immunosensor for sensitive detection of Ochratoxin A. Biosens. Bioelectron. 2015, 64, 13-18. [CrossRef] [PubMed]

58. Kuang, H.; Chen, W.; Xu, D.; Xu, L.; Zhu, Y.; Liu, L.; Chu, H.; Peng, C.; Xu, C.; Zhu, S. Fabricated aptamer-based electrochemical "signal-off" sensor of ochratoxin A. Biosens. Bioelectron. 2010, 26, 710-716. [CrossRef] [PubMed]

59. Prabhakar, N.; Matharu, Z.; Malhotra, B.D. Polyaniline Langmuir-Blodgett film based aptasensor for ochratoxin A detection. Biosens. Bioelectron. 2011, 26, 4006-4011. [CrossRef] [PubMed]

60. Tong, P.; Zhang, L.; Xu, J.J.; Chen, H.Y. Simply amplified electrochemical aptasensor of Ochratoxin A based on exonuclease-catalyzed target recycling. Biosens. Bioelectron. 2011, 29, 97-101. [CrossRef] [PubMed] 
61. Zhang, J.; Chen, J.; Zhang, X.; Zeng, Z.; Chen, M.; Wang, S. An electrochemical biosensor based on hairpin-DNA aptamer probe and restriction endonuclease for ochratoxin A detection. Electrochem. Commun. 2012, 25, 5-7. [CrossRef]

62. Hayat, A.; Andreescu, S.; Marty, J.L. Design of PEG-aptamer two piece macromolecules as convenient and integrated sensing platform: Application to the label-free detection of small size molecules. Biosens. Bioelectron. 2013, 45, 168-173. [CrossRef] [PubMed]

63. Bazin, I.; Andreotti, N.; Hassine, A.I.; De Waard, M.; Sabatier, J.M.; Gonzalez, C. Peptide binding to ochratoxin A mycotoxin: A new approach in conception of biosensors. Biosens. Bioelectron. 2013, 40, 240-246. [CrossRef] [PubMed]

64. Heurich, M.; Altintas, Z.; Tothill, I.E. Computational Design of Peptide Ligands for Ochratoxin A. Toxins 2013, 5, 1202-1218. [CrossRef] [PubMed]

65. Soleri, R.; Demey, H.; Tria, S.A.; Guiseppi-Elie, A.; Hassine, A.I.; Gonzalez, C.; Bazin, I. Peptide conjugated chitosan foam as a novel approach for capture-purification and rapid detection of hapten-Example of ochratoxin A. Biosens. Bioelectron. 2015, 67, 634-641. [CrossRef] [PubMed]

66. Padeste, C.; Grubelnik, A.; Tiefenauer, L. Amperometric immunosensing using microperoxidase MP-11 antibody conjugates. Anal. Chim. Acta 1998, 374, 167-176. [CrossRef]

67. Kuramitz, H.; Matsuda, M.; Thomas, J.H.; Sugawara, K.; Tanaka, S. Electrochemical immunoassay at a 17 beta-estradiol self-assembled monolayer electrode using a redox marker. Analyst 2003, 128, 182-186. [CrossRef] [PubMed]

68. Pemberton, R.M.; Mottram, T.T.; Hart, J.P. Development of a screen-printed carbon electrochemical immunosensor for picomolar concentrations of estradiol in human serum extracts. J. Biochem. Biophys. Methods 2005, 63, 201-212. [CrossRef] [PubMed]

69. Butler, D.; Guilbault, G.G. Disposable amperometric immunosensor for the detection of 17-beta estradiol using screen-printed electrodes. Sens. Actuators B Chem. 2006, 113, 692-699. [CrossRef]

70. Volpe, G.; Fares, G.; Quadri, F.; delli Draisci, R.; Ferretti, G.; Marchiafava, C.; Moscone, D.; Palleschi, G. A disposable immunosensor for detection of 17 beta-estradiol in non-extracted bovine serum. Anal. Chim. Acta 2006, 572, 11-16. [CrossRef] [PubMed]

71. Liu, X.; Wong, D.K.Y. Picogram-detection of estradiol at an electrochemical immunosensor with a gold nanoparticle vertical bar Protein G-(LC-SPDP)-scaffold. Talanta 2009, 77, 1437-1443. [CrossRef] [PubMed]

72. Liu, X.; Duckworth, P.A.; Wong, D.K.Y. Square wave voltammetry versus electrochemical impedance spectroscopy as a rapid detection technique at electrochemical immunosensors. Biosens. Bioelectron. 2010, 25, 1467-1473. [CrossRef] [PubMed]

73. Martinez, N.A.; Schneider, R.J.; Messina, G.A.; Raba, J. Modified paramagnetic beads in a microfluidic system for the determination of ethinylestradiol (EE2) in river water samples. Biosens. Bioelectron. 2010, 25, 1376-1381. [CrossRef] [PubMed]

74. Kim, B.K.; Li, J.; Im, J.E.; Ahn, K.S.; Park, T.S.; Cho, S.I.; Kim, Y.R.; Lee, W.Y. Impedometric estrogen biosensor based on estrogen receptor alpha-immobilized gold electrode. J. Electroanal. Chem. 2012, 671, 106-111. [CrossRef]

75. Liu, X.; Wang, X.; Zhang, J.; Feng, H.; Liu, X.; Wong, D.K.Y. Detection of estradiol at an electrochemical immunosensor with a Cu UPD vertical bar DTBP-Protein G scaffold. Biosens. Bioelectron. 2012, 35, 56-62. [CrossRef] [PubMed]

76. Ojeda, I.; Lopez-Montero, J.; Moreno-Guzman, M.; Janegitz, B.C.; Gonzalez-Cortes, A.; Yanez-Sedeno, P.; Pingarron, J.M. Electrochemical immunosensor for rapid and sensitive determination of estradiol. Anal. Chim. Acta 2012, 743, 117-124. [CrossRef] [PubMed]

77. Kanso, H.; Barthelmebs, L.; Inguimbert, N.; Noguer, T. Immunosensors for Estradiol and Ethinylestradiol Based on New Synthetic Estrogen Derivatives: Application to Wastewater Analysis. Anal. Chem. 2013, 85, 2397-2404. [CrossRef] [PubMed]

78. Chaisuwan, N.; Xu, H.; Wu, G.; Liu, J. A highly sensitive differential pulse anodic stripping voltammetry for determination of 17 beta-estradiol (E2) using CdSe quantum dots based on indirect competitive immunoassay. Biosens. Bioelectron. 2013, 46, 150-154. [CrossRef] [PubMed]

79. Li, J.; Liu, S.; Yu, J.; Lian, W.; Cui, M.; Xu, W.; Huang, J. Electrochemical immunosensor based on graphene-polyaniline composites and carboxylated graphene oxide for estradiol detection. Sens. Actuators B Chem. 2013, 188, 99-105. [CrossRef] 
80. Zhang, S.; Wang, Y.; Zhang, Y.; Yan, T.; Yan, L.; Wei, Q.; Du, B. An ultrasensitive electrochemical immunosensor for determination of estradiol using coralloid $\mathrm{Cu}_{2} \mathrm{~S}$ nanostructures as labels. RSC Adv. 2015, 5, 6512-6517. [CrossRef]

81. Zhang, S.; Du, B.; Li, H.; Xin, X.; Ma, H.; Wu, D.; Yan, L.; Wei, Q. Metal ions-based immunosensor for simultaneous determination of estradiol and diethylstilbestrol. Biosens. Bioelectron. 2014, 52, 225-231. [CrossRef] [PubMed]

82. Monerris, M.J.; Arévalo, F.J.; Fernández, H.; Zon, M.A.; Molina, P.G. Development of a very sensitive electrochemical immunosensor for the determination of $17 \beta$-estradiol in bovine serum samples. Sens. Actuators B Chem. 2015, 208, 525-531. [CrossRef]

83. Olowu, R.A.; Arotiba, O.; Mailu, S.N.; Waryo, T.T.; Baker, P.; Iwuoha, E. Electrochemical Aptasensor for Endocrine Disrupting 17 beta-Estradiol Based on a Poly(3,4-ethylenedioxylthiopene)-Gold Nanocomposite Platform. Sensors 2010, 10, 9872-9890. [CrossRef] [PubMed]

84. Lin, Z.; Chen, L.; Zhang, G.; Liu, Q.; Qiu, B.; Cai, Z.; Chen, G. Label-free aptamer-based electrochemical impedance biosensor for 17 beta-estradiol. Analyst 2012, 137, 819-822. [CrossRef] [PubMed]

85. Huang, K.J.; Liu, Y.J.; Shi, G.W.; Yang, X.R.; Liu, Y.M. Label-free aptamer sensor for 17 beta-estradiol based on vanadium disulfide nanoflowers and Au nanoparticles. Sens. Actuators B Chem. 2014, 201, 579-585. [CrossRef]

86. Ke, H.; Liu, M.; Zhuang, L.; Li, Z.; Fan, L.; Zhao, G. A Fetomolar Level 17 beta-estradiol Electrochemical Aptasensor Constructed On Hierachical Dendritic Gold Modified Boron-Doped Diamond Electrode. Electrochim. Acta 2014, 137, 146-153. [CrossRef]

87. Zhu, B.; Alsager, O.A.; Kumar, S.; Hodgkiss, J.M.; Travas-Sejdic, J. Label-free electrochemical aptasensor for femtomolar detection of 17 beta-estradiol. Biosens. Bioelectron. 2015, 70, 398-403. [CrossRef] [PubMed]

88. Fan, L.; Zhao, G.; Shi, H.; Liu, M. A simple and label-free aptasensor based on nickel hexacyanoferrate nanoparticles as signal probe for highly sensitive detection of $17 \beta$-estradiol. Biosens. Bioelectron. 2015, 68, 303-309. [CrossRef] [PubMed]

89. Jimenez, G.C.; Eissa, S.; Ng, A. Aptamer-Based Label-Free Impedimetric Biosensor for Detection of Progesterone. Anal. Chem. 2015, 87, 1075-1082. [CrossRef] [PubMed]

(C) 2016 by the authors; licensee MDPI, Basel, Switzerland. This article is an open access article distributed under the terms and conditions of the Creative Commons by Attribution (CC-BY) license (http://creativecommons.org/licenses/by/4.0/). 